\title{
Spillover from six western Mediterranean marine protected areas: evidence from artisanal fisheries
}

\author{
R. Goñi ${ }^{1, *}$, S. Adlerstein ${ }^{2}$, D. Alvarez-Berastegui ${ }^{1}$, A. Forcada ${ }^{3}$, O. Reñones ${ }^{1}$, G. Criquet $^{4}$, \\ S. Polti ${ }^{5}$, G. Cadiou ${ }^{6}$, C. Valle ${ }^{3}$, P. Lenfant ${ }^{4}$, P. Bonhomme ${ }^{6}$, A. Pérez-Ruzafa ${ }^{5}$, \\ J. L. Sánchez-Lizaso ${ }^{3}$, J. A. García-Charton ${ }^{5}$, G. Bernard ${ }^{6}$, V. Stelzenmüller ${ }^{7}$, S. Planes ${ }^{4}$ \\ ${ }^{1}$ Centro Oceanográfico de Baleares - IEO - Muelle de Poniente s/n, 07015 Palma de Mallorca, Spain \\ ${ }^{2}$ School of Natural Resources and Environment, University of Michigan, 3010 Dana Building, Ann Arbor, \\ Michigan 48109-1115, USA
}

${ }^{3}$ Departamento de Ciencias del Mar y Biología Aplicada, Universidad de Alicante, Campus de San Vicente del Raspeig, Apd. 99, 03080 Alicante, Spain

${ }^{4}$ Laboratoire Ecosystèmes Aquatiques Tropicaux et Méditerranéens, UMR 5244 CNRS - EPHE - Université Via Domitia, 52 avenue Paul Alduy, 66860 Perpignan Cedex, France

${ }^{5}$ Departamento de Ecología e Hidrología, Universidad de Murcia, Campus de Epinardo 30100 Murcia, Spain ${ }^{6}$ GIS Posidonie, Parc Scientifique et Technologique de Luminy, CP 901, 13288 Marseille Cedex 09, France

${ }^{7}$ CEFAS, Pakefield Road, Lowestoft, Suffolk NR33 DHT, UK

\begin{abstract}
This study investigated spillover (biomass export) around 6 marine protected areas (MPAs) in the western Mediterranean based on catch and effort data from artisanal fisheries. The selected MPAs were Cerbère-Banyuls and Carry-le-Rouet in France, and Medes, Cabrera, Tabarca, and Cabo de Palos in Spain. These MPAs had been functional for more than $8 \mathrm{yr}$ and incorporate areas of fisheries closure and restricted use where fishing is limited. We based our study on the hypotheses that, in the presence of biomass export, (1) fishing effort would concentrate close to MPA boundaries, and (2) fishery production, expressed as catch per unit area (CPUA), would be highest near MPA boundaries and decrease with distance. We selected data from 14 'fishing tactics' using gill nets, trammel nets and bottom long-lines targeting sparids, mullids, serranids, scorpaenids and palinurids. We analyzed the spatial distribution of effort, fishery production and revenues per unit area, using generalized additive models (GAMs), and we tested regression slopes of effort density and CPUA with distance to closure boundaries, using generalized linear models (GLMs). GAMs allowed us to recognize habitat discontinuities or 'hot spots' of high production in the vicinity of the MPAs, and to identify the extent of potential spillover effects in order to implement GLMs. We found evidence of effort concentration and high fishery production near fisheries closures for all fishing tactics analyzed and significant negative slopes for most. Revenues generally followed trends similar to CPUA. Significant negative slopes from GLM of effort density and CPUA with distance from fisheries closures were indicative of biomass export where habitats across closure boundaries had some degree of continuity. The spatial extent of spillover was consistent with species mobility and fisheries efficiency and extended 700 to $2500 \mathrm{~m}$ from fishery closure boundaries. Our results suggest that coastal MPAs can be an effective management tool for artisanal fisheries in the region and can be extended to the rest of the western Mediterranean, as the fishing tactics studied are typical of the region.
\end{abstract}

KEY WORDS: Marine protected areas • Fisheries closures • Artisanal fisheries · Spillover · Fishing the line $\cdot$ Catch gradients $\cdot$ Mediterranean Sea

\section{INTRODUCTION}

Fishing restrictions in marine protected areas (MPAs) can promote increases in biomass of exploited species, which under particular conditions will lead to spillover (i.e. biomass export) to surrounding non-protected areas, maintaining or enhancing local fisheries (e.g. reviews in Roberts \& Polunin 1991, Sánchez-Lizaso et al. 2000, Russ 2002). Species that have shown strong responses to protection are those that have moderate vagility in relation 
to the size of the protected area and are subjected to high levels of fishing mortality (Kramer \& Chapman 1999). Mechanisms leading to adult export from MPAs are density-dependent movements of competitively subordinate individuals from preferred habitats (Dugan \& Davis 1993, Abesamis \& Russ 2005), seasonal migrations (McClanahan \& Mangi 2000, Kaunda-Arara \& Rose 2004) or random and home range movements or relocation (Rakitin \& Kramer 1996, Kramer \& Chapman 1999, Tupper 2007). Therefore spillover depends not only on biomass increase within protected areas but also on fish mobility and habitat characteristics around MPAs. Spatially, spillover should result in higher fish densities close to the borders of the MPA that decrease with distance, with specific patterns shaped by fish mobility and mortality imposed by fisheries in surrounding areas (Rakitin \& Kramer 1996, Chapman \& Kramer 1999, Russ et al. 2003). In fisheries adjacent to MPAs, spillover is expected to translate into aggregation of effort (Kellner et al. 2007) and increased catches (Murawski et al. 2005, Goñi et al. 2006, Abesamis et al. 2006a).

Theoretical studies of the effects of MPAs on fisheries (e.g. Gerber et al. 2003, Rodwell \& Roberts 2004, Hilborn et al. 2006 and references therein) outnumber empirical evidence. These studies have generally assessed merits of MPAs for attaining single species yield stability and sustainability. In contrast the aims of empirical studies of MPA effects on fisheries have so far been modest, focusing on ascertaining the distribution of fishing effort and/or catches near MPAs. Several studies have demonstrated fishing effort aggregation along MPA boundaries (e.g. Yamasaki \& Kuwahara 1989, McClanahan \& Kaunda-Arara 1996, Johnson et al. 1999, McClanahan \& Mangi 2000, Kelly et al. 2002, Willis et al. 2003, Beukers-Stewart et al. 2005, Goñi et al. 2006, Murawski et al. 2005), suggesting spillover of biomass to adjacent fisheries. To evaluate MPA effects on fishery catches some studies have monitored catch per unit effort (CPUE) over time in grounds adjacent to MPAs and have demonstrated increases in CPUE of target species after MPA creation (e.g. Yamasaki \& Kuwahara 1989, McClanahan \& Kaunda-Arara 1996, McClanahan \& Mangi 2000, Roberts et al. 2001, Galal et al. 2002, Russ et al. 2004, Beukers-Stewart et al. 2005) or declines after MPA protection ended (Alcalá \& Russ 1990). Other studies have measured gradients of CPUE across or near MPA boundaries, and found higher yields immediately adjacent to MPAs, with gradients extending from a few hundred to several thousand meters away for species of low to moderate mobility (e.g. McClanahan \& Kaunda-Arara 1996, Rakitin \& Kramer 1996, Russ \& Alcala 1996, Chapman \& Kramer 1999, Kaunda-Arara \& Rose 2004, Murawski et al. 2005, Abesamis et al. 2006a). Studies of MPA effects on lobster fisheries have reported similar results (Kelly et al. 2002, Davidson et al. 2002, Goñi et al. 2006). With the exception of the lobster studies and those of Murawski et al. (2005) and Beukers-Stewart et al. (2005) which were conducted in temperate ecosystems, most of this work has been done on coral reef fisheries. In the Mediterranean Sea, only one study has evaluated spillover effects of an MPA on adjacent artisanal fisheries (Goñi et al. 2006), demonstrating effort concentration and gradients of lobster catches extending up to $1500 \mathrm{~m}$ from MPA boundaries.

MPA benefits to fisheries have been difficult to demonstrate empirically because studies are troubled by site specificity and lack of management replication and base-line data (Dugan \& Davis 1993, Russ 2002). Also, few studies have investigated spillover for long enough periods to see the effects fully developed (Russ et al. 2004). Further, scales and effects of additional factors (e.g. habitat, depth) on density gradients confound interpretation (García-Charton \& Pérez-Ruzafa 1999). As a result, no study has yet demonstrated net biomass export from an MPA to the adjacent fishery, although strong evidence is becoming available. For example Russ et al. (2004) demonstrated the build-up of reef fish biomass for over 2 decades adjacent to the Apo MPA in the Philippines, and Abesamis et al. (2006a) estimated the potential maximum contribution of spillover from the MPA at less than $10 \%$ of the overall yield of the Apo Island fisheries. In a tag-recapture study Goñi et al. (2006) demonstrated the existence of negative gradients of CPUE of both tagged and untagged lobster from the boundary of a Mediterranean MPA where tagged lobster originated. More recently Tupper (2007) demonstrated net outward movement of tagged surgeonfish from an MPA in Micronesia, but little or no spillover of 4 other exploited fish species, and concluded that spillover was species-specific and influenced by reef topography.

Marine protected areas have become a popular management tool in the Mediterranean Sea, with the last census reporting 85 in the region (Ramos-Esplá et al. 2004). Research on the benefits of MPAs in the area has focused on rocky-littoral fish assemblages using underwater visual census (UVC) techniques, although some studies have targeted seagrass fish assemblages and invertebrate populations (Sánchez-Lizaso et al. 2000). The primary objective of these studies has been to evaluate population recoveries inside MPAs, and only recently has attention been directed to assessing density gradients across MPA boundaries. Biomass buildup inside Western Mediterranean MPAs has occurred, despite their relatively small size, because of previous high exploitation rates and the limited mobility of target species. Studies generally report significantly higher biomass inside than outside MPAs of Sparidae, Ser- 
ranidae, Scorpaenidae, Labridae, Congridae, Muraenidae and Palinuridae species (Harmelin-Vivien et al. 1985, García-Rubies 1997, García-Charton et al. 2004, Jouvenel et al. 2004, Michelli et al. 2005, Planes 2005, Goñi et al. 2006, Ojeda-Martinez et al. 2007). Species from these taxa are either sedentary (Scorpaenidae, Muraenidae, Congridae) or exhibit low (Serranidae, Labridae) to moderate (Sparidae, Mullidae, Palinuridae) mobility (Harmelin 1987, Goñi \& Latrouite 2005).

The objective of this study was to investigate spillover from 6 MPAs in the Western Mediterranean based on effects on artisanal fisheries. The study focused on fisheries operating fixed gears and targeting a variety of littoral species in and around 6 MPAs. Artisanal fisheries in the region are characterized by the use of particular gears targeting species or groups of species in certain habitats and seasons (i.e. 'fishing tactics'; see Pelletier \& Ferraris 2000). Prior to this study, fleets and fishing tactics operating around the MPAs selected for study were largely unknown. Thus, our first objective was to characterize the fisheries associated with each MPA and to select fishing tactics targeting groups of species with different spillover potential. Then, we examined the spatial distribution of fishing effort and catch around the MPAs and hypothesized that, in the presence of biomass export, (1) fishing effort would concentrate on the boundary of the MPAs, and (2) catch per unit area would be highest near MPA boundaries and decrease with distance away from MPAs. We hypothesized that fisheries targeting Sparidae, Mullidae, Palinuridae, Serranidae, and Scorpaenidae species could benefit from spillover near MPAs (providing there was continuity of habitats through MPA boundaries), and that the spatial extent of spillover would vary from a maximum in fisheries catching species of moderate mobility (such as Sparidae) to a minimum in those catching species of very restricted mobility (such as Scorpaenidae).

\section{MATERIALS AND METHODS}

General approach. To test the hypothesis of biomass export we investigated the spatial distribution of effort density and catch per unit area as a function of distance from fishery closure (FC) boundaries. This approach follows that of several studies that have assessed spillover based on gradients of fish density and fishing effort away from MPA boundaries (e.g. McClanahan \& Kaunda-Arara 1996, Russ et al. 2003, 2004, Murawski et al. 2005, Abesamis et al. 2006a). However, while those studies used CPUE as the density index, we used CPUA as a measure of production, as was also done by Goñi et al. (2006) and McClanahan \& Mangi (2000), to consider potential local abundance depletion that may be caused by aggregation of effort near MPA boundaries (Walters 2000). Depletion affects spatial CPUE patterns and can hamper assessing MPA effects to adjacent fisheries. We analyzed CPUA of the combined catch rather than the catch by species because artisanal fisheries in the region have nominal targets but aim at optimizing the aggregated catch.

This study was part of a multidisciplinary European research project (BIOMEX, http://biomex.univ-perp. fr/). In addition to the assessment of MPA effects on artisanal fisheries from 6 Western Mediterranean MPAs, the BIOMEX study assessed export of eggs/larvae and adult spillover through the evaluation of biomass gradients by UVC, baited video and experimental fishing (Planes 2005). Prior to this study, investigation of MPA fishery benefits in the Mediterranean had only been carried out on a single-MPA basis.

Study area. This study was carried out in the MPAs of Carry-le-Rouet Natural Park (hereafter called Carry), Cerbère-Banyuls Marine Natural Reserve (Banyuls), Medes Islands Marine Reserve (Medes), Tabarca Island Marine Reserve (Tabarca), Cabrera Archipelago National Park (Cabrera), and Cabo de Palos-Islas Hormigas Marine Reserve (Cabo de Palos) (Fig. 1). These MPAs were selected because they were all established at least $8 \mathrm{yr}$ prior to our study (Table 1) and evidence of population recovery of exploited species was available (Carry: Harmelin et al. 1995; Banyuls: Bell 1983, Dufour et al. 1995; Medes: GarcíaRubies \& Zabala 1990; Cabrera: García-Rubies 1997, Reñones et al. 1999; Tabarca: Bayle-Sempere 1999;

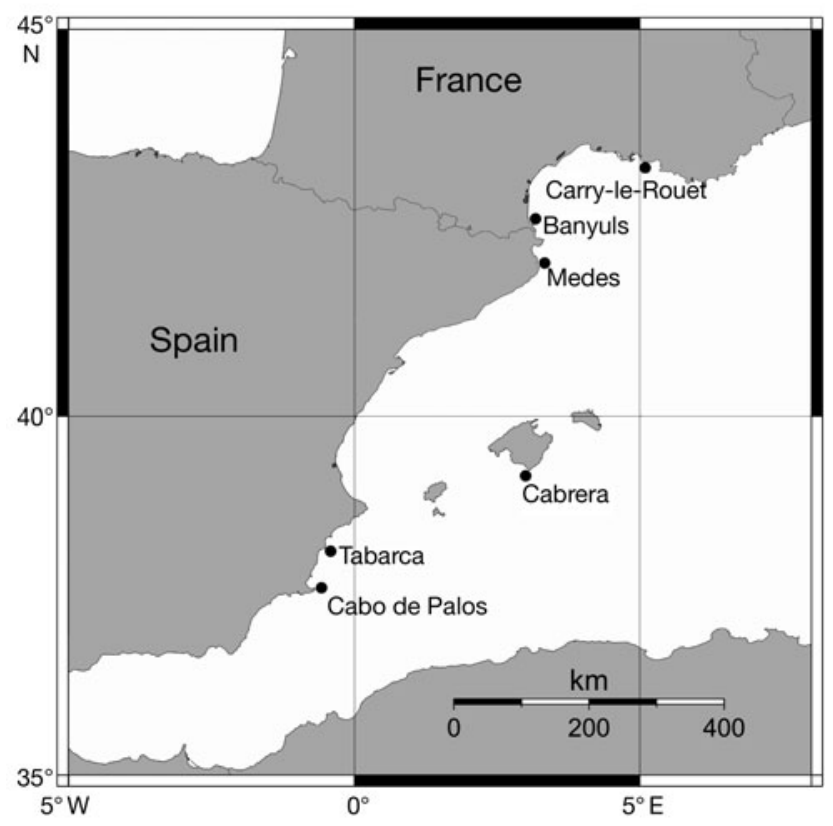

Fig. 1. Location of the western Mediterranean marine protected areas included in the study 
Table 1. General characteristics of marine protected areas (MPA) selected for the study. Year = year of MPA establishment, FC = fisheries closure area, RU = restricted use area. Depth = maximum within areas. Main habitat types ranked based on proportion of area covered

\begin{tabular}{|c|c|c|c|c|c|c|c|c|}
\hline \multirow[t]{2}{*}{ MPA } & \multirow[t]{2}{*}{ Year } & \multirow[t]{2}{*}{ Type } & \multicolumn{2}{|c|}{ Area $\left(\mathrm{km}^{2}\right)$} & \multicolumn{2}{|c|}{ Depth (m) } & \multicolumn{2}{|c|}{ Main habitats } \\
\hline & & & $\mathrm{FC}$ & RU & $\mathrm{FC}$ & $\mathrm{RU}$ & $\mathrm{FC}$ & RU \& adjacent \\
\hline Carry & 1982 & Coastal & 0.85 & 0 & 30 & 30 & $\begin{array}{l}\text { Seagrass meadows } \\
\text { Rocky photophylic }\end{array}$ & $\begin{array}{l}\text { Seagrass meadows } \\
\text { Rocky photophylic }\end{array}$ \\
\hline Banyuls & 1974 & Coastal & 0.65 & 5.85 & 45 & 60 & $\begin{array}{l}\text { Soft sandy } \\
\text { Rocky photophylic } \\
\text { Rocky coralligenous }\end{array}$ & $\begin{array}{l}\text { Soft sandy } \\
\text { Rocky photophylic } \\
\text { Rocky coralligenous }\end{array}$ \\
\hline Medes & 1983 & Island & 0.93 & 4.18 & 60 & 60 & $\begin{array}{l}\text { Rocky coralligenous } \\
\text { Rocky photophylic } \\
\text { Soft sandy substrate }\end{array}$ & $\begin{array}{l}\text { Soft sandy / muddy } \\
\text { Seagrass meadows }\end{array}$ \\
\hline Cabrera $^{a}$ & 1991 & Island & 2.34 & 84.66 & 55 & 110 & $\begin{array}{l}\text { Rocky photophylic } \\
\text { Seagrass meadows } \\
\text { Soft sandy }\end{array}$ & $\begin{array}{l}\text { Rocky photophylic } \\
\text { Soft sandy } \\
\text { Soft detritic / maërl }\end{array}$ \\
\hline Tabarca & 1986 & Island & 1.00 & 13.00 & 20 & 40 & $\begin{array}{l}\text { Seagrass meadows } \\
\text { Rocky photophylic }\end{array}$ & $\begin{array}{l}\text { Seagrass meadows } \\
\text { Soft sandy } \\
\text { Rocky photophylic }\end{array}$ \\
\hline Cabo de Palos & 1995 & Coastal & 2.70 & 16.28 & 80 & 100 & $\begin{array}{l}\text { Soft detritic / maërl } \\
\text { Rocky coralligenous } \\
\text { Rocky coralligenous }\end{array}$ & $\begin{array}{l}\text { Soft detritic / maërl } \\
\text { Rocky photophylic } \\
\text { Rocky photophylic }\end{array}$ \\
\hline
\end{tabular}

Cabo de Palos: García-Charton \& Pérez-Ruzafa 1999, García-Charton et al. 2004). The selected MPAs are case studies for the Mediterranean, representative of islands or island groups and coastal strips protecting mainly shallow (<60 m) littoral ecosystems (Table 1). As in most Western Mediterranean MPAs, commercial fishery regulations include 2 zoning levels: (1) a fisheries closure (FC) area where all fishing activities are excluded, and (2) a restricted use (RU) area where some fishing is allowed, usually small scale artisanal fisheries (Table 1). Beyond these areas, MPAs are surrounded by open fishing waters. Carry does not have a RU area and the whole MPA is an FC. Similarly, in Tabarca fishing in the RU area is allowed only for pelagic species, thus for the purpose of this study the whole MPA is considered an FC. The size of FC areas among MPAs ranged from 0.65 to $2.7 \mathrm{~km}^{2}$ and the size of RU areas from 0 to $84.66 \mathrm{~km}^{2}$ (Table 1).

The spatial configuration and habitat characteristics vary among MPAs in the study. Cabrera presents sharper bathymetric gradients near FC boundaries than Medes and Cabo de Palos, and in Banyuls, Carry, and Tabarca gradients are minor (Fig. 2). Whereas in Cabrera the FC area consists of a string of unconnected bays, in the other MPAs it is a continuous area. The FC areas in Banyuls, Medes, Cabrera, and Cabo de Palos are all dominated by rocky habitats, while the RU and surrounding fishing areas are a mix of rock, gravel-sand, and sea-grass substrates, with the exception of Medes where RU and open fishing areas are dominated by soft bottoms (Table 1, Fig. 2). In Carry and Tabarca FCs and surrounding areas Posidonia oceanica meadows are the dominant habitat (Table 1, Fig. 2). In all MPAs, habitats and depth in the RU areas are at least in some parts similar to those in the adjacent fishing areas (Fig. 2).

Sampling. Catch and effort data were collected during 2003 and 2004 onboard artisanal commercial fishing operations conducted within RU and open fishing areas adjacent to each MPA. For all fishing sets sampled, catch was identified to the species level and enumerated. Fish were measured and weighed. The date, geographic positions of the start and end of each fishing set, and occasionally intermediate positions, were recorded. For long-line fisheries the number and mean distance between hooks were recorded. For gill net and trammel net fisheries the length of the gear was recorded. During 2003, fisher interviews in nearby fishing harbors were also conducted. Since prior information on local fisheries was lacking, data collected onboard in 2003 covered all artisanal fishing activities in the study areas. These data, and information obtained during fisher interviews, were used to characterize fishing tactics operating in and around the MPAs and to select fishing tactics for data collection in 2004.

During 2003, a total of 212 fishing sets were sampled. Interviews and onboard sampling confirmed that fisheries around all MPAs were diverse and followed a variety of fishing tactics, and that the size of the vessels was small and fairly homogeneous (6 to $11 \mathrm{~m}$ ). The most common tactics used gill nets, trammel nets, and long-lines. Between 5 and 14 fishing tactics were identified within 
each MPA and nearby fishing grounds (49 in total). Based on the information gathered during 2003, we selected 14 fishing tactics on which to focus sampling during 2004 (Table 2). For the selection we used the following information and criteria: (1) the spatial dynamics of the fishing tactics, selecting those that occurred in grounds close to FCs, (2) the relative importance of each fishing tactic, selecting those with greatest fishing effort deployed by the largest number of boats, and (3) the species composition of catches, selecting those tactics catching highly exploited, non-migratory, benthic or nectobenthic species with suitable habitats within the FC areas. The selected fishing tactics used gill nets or a combination of gill nets and trammel nets to target various sparids, trammel nets to target mullids, scorpaenids, and palinurids, and bottom long-lines to target sparids and serranids (Table 2). Tactics targeting sparids were the most ubiquitous and used combined nets in Carry and Banyuls, gill nets in Medes and Tabarca, and long-lines in Tabarca and Cabrera (Table 2). The selected tactics operated both in RU and adjacent open fishing areas, ex- cept in Carry and Tabarca where they only operated in open fishing areas and in Cabrera where they operated in the extensive RU area. Fishing tactics that were not selected for analysis targeted migratory species (e.g. Cabrera and Cabo de Palos: pelagic trammel nets) or species whose habitats were not present within FC areas (e.g. Carry and Banyuls: hake gill nets; Cabrera: lobster trammel nets). Other tactics were not considered because fishing effort was too low (e.g. Tabarca: sparid trammel nets; Cabrera: grouper hand line) or did not take place close to MPAs (e.g. Tabarca: cuttle fish trammel net; Cabo de Palos: dentex long-line).

During 2004, 488 fishing sets were sampled, of which we retained data from 399 for the spillover gradient analysis. Discarded sets were deployed too far from the potential areas of influence of the MPAs or were not directed to the fishing tactics selected for the study (boats could combine more than one fishing tactic on the same trip). Based on our estimates of total fishing days and number of boats operating around each MPA, our sampling effort covered about $5 \%$ of the

Table 2. Seasonality and catch composition of the fishing tactics selected for analysis of spillover in each marine protected area (MPA). 'Combined' tactics = gill and trammel net. Catch composition = proportion of retained catch (excluding pelagics), given for families that constituted $\geq 10 \%$ by number. Target $\left({ }^{*}\right)$ and main non-target species are indicated in brackets

\begin{tabular}{|c|c|c|c|c|}
\hline MPA & Fishing tactic & Season & Family & al abundance \\
\hline \multirow[t]{4}{*}{ Carry } & Sparids combined & Mar-Dec & Sparidae (Sparus aurata*, Diplodus spp., Salpa salpa) & 68 \\
\hline & Mullet trammel net & Mar-Nov & Mullidae (Mullus surmuletus*) & 33 \\
\hline & & & Scorpaenidae & 16 \\
\hline & & & Labridae & 10 \\
\hline \multirow[t]{2}{*}{ Banyuls } & Sparids combined & Apr-Sep & Sparidae (Sparus aurata*, Pagellus spp., Diplodus spp.) & 44 \\
\hline & Lobster trammel net & Jun-Dec & Palinuridae (Palinurus elephas* & $\begin{array}{l}63 \\
10\end{array}$ \\
\hline \multirow[t]{3}{*}{ Medes } & Sparids gill net & Sep-Dec & Sparidae (Pagellus erythrinus*, Pagellus bogaraveo*) & 41 \\
\hline & Mullet trammel net & May-Nov & Mullidae (Mullus surmuletus*) & 29 \\
\hline & & & Sparidae & 21 \\
\hline \multirow[t]{7}{*}{ Cabrera } & Grouper long-line & Sep-Dec & Serranidae (Epinephelus marginatus* ${ }^{*}$, Serranus cabrilla) & 23 \\
\hline & & & Sparidae (Pagrus pagrus*, Dentex dentex) & 28 \\
\hline & Sparids long-line & Jan-May & $\begin{array}{l}\text { Sparidae (Pagrus pagrus* }{ }^{*} \text { Spondyliosoma cantharus) } \\
\text { Scyliorihinidae }\end{array}$ & $\begin{array}{l}16 \\
58\end{array}$ \\
\hline & Rockfish trammel net & May-Aug & Scorpaenidae (Scorpaena scrofa* $\left.{ }^{*}\right)$ & 13 \\
\hline & & & Palinuridae (Palinurus elephas*) & 10 \\
\hline & & & Scyliorhinidae & 12 \\
\hline & & & Sparidae & 11 \\
\hline \multirow[t]{7}{*}{ Tabarca } & Sparids long-line & Jan-Dec & Sparidae (Diplodus spp. ${ }^{*}$, Pagrus pagrus ${ }^{*}$ ) & 33 \\
\hline & & & Moronidae & 23 \\
\hline & & & Congridae & 21 \\
\hline & Sparids gill net & Jan-Dec & Sparidae (Dentex dentex ${ }^{*}$, Diplodus sargus* ${ }^{*}$ Sparus aurata*) & 24 \\
\hline & Mullet trammel net & Jan-Dec & Mullidae (Mullus surmuletus*) & 40 \\
\hline & & & Serranidae & 11 \\
\hline & & & Sparidae & 10 \\
\hline \multirow{5}{*}{$\begin{array}{l}\text { Cabo de } \\
\text { Palos }\end{array}$} & Rockfish trammel net & May-Sep & Scorpaenidae (Scorpaena scrofa ${ }^{*}, S$. porcus) & 37 \\
\hline & & & Sparidae & 15 \\
\hline & Lobster trammel net & May-Sep & Palinuridae (Palinurus elephas*) & 20 \\
\hline & & & Scorpaenidae & 47 \\
\hline & & & Sparidae & 19 \\
\hline
\end{tabular}




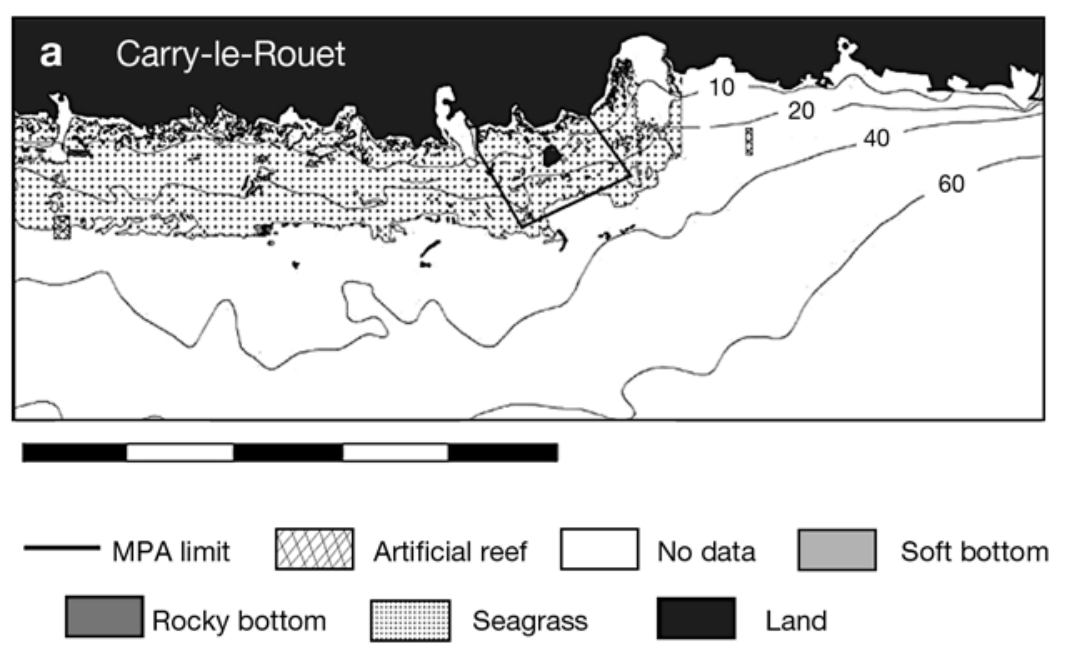

Fig. 2. Habitat and bathymetry map of the study area in the marine protected areas (MPAs) of (a) Carry, (b) Banyuls, (c) Medes, (d) Cabrera, (e) Tabarca and (f) Cabo de Palos. Polygons or circles inside the relevant MPAs are fisheries closure areas. Scale bars $=5 \mathrm{~km}$. Depth contours in metres

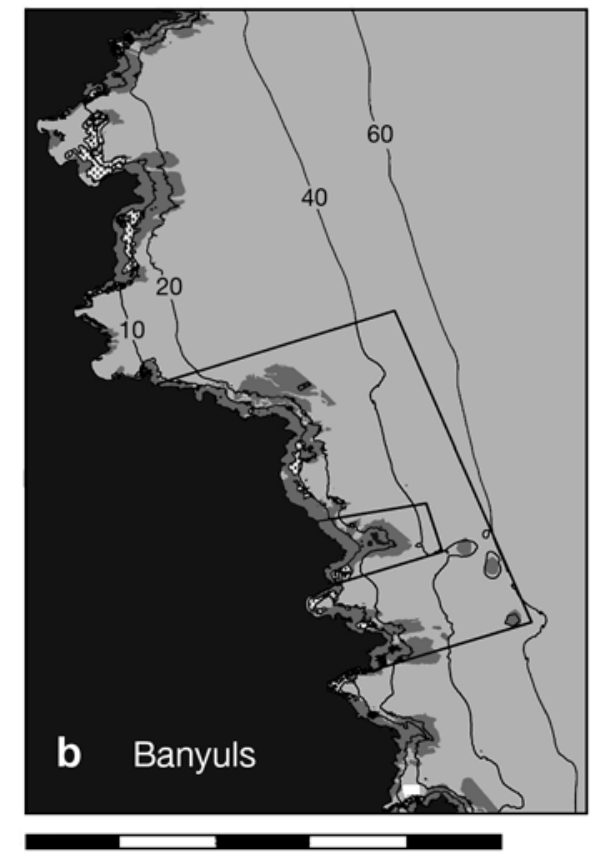

total effort conducted by the selected fishing tactics in Carry, Tabarca and Cabo de Palos, $13 \%$ in Medes and Cabrera, and $33 \%$ in Banyuls.

The catches from the selected fishing tactics were highly diverse but dominated by a restricted number of species with moderate to low mobility. Discards were low and included low value species caught in small quantities or small pelagics caught accidentally. There were up to 76 species identified in a single tactic but 16 species belonging to 10 families made up $10 \%$ or more of the retained catch. The contribution of target taxa to the retained catch (by number, excluding pelagics) varied from $68 \%$ in the Carry sparid tactic to $13 \%$ in the Cabrera rockfish tactic (Table 2). Sparidae were the most abundant taxa in 11 of the 14 tactics studied.

Mean effort and retained catch per set ranged from generally lowest levels in long-line fishing tactics to highest among mullet trammel net fishing tactics. In the sparid and grouper long-line tactics, mean effort and retained catch ranged from 94 to 144 hooks and 4.1 to 10.5 fish per set, in the sparid gill net tactics from 627 to $1114 \mathrm{~m}$ of net and 5.7 to 17.3 fish per set, in the rockfish and lobster trammel net tactics from 591 to $1874 \mathrm{~m}$ of net and 3.5 to 50.6 individuals per set, and in the mullet trammel net tactics from 973 to $1578 \mathrm{~m}$ of net and 17.3 to 179.9 fish per set.

Data handling. The study area around each MPA was divided in square cells and for each fishing tactic we calculated effort density and catch per unit area (CPUA) by cell. We used GIS ESRI ${ }^{\circledR}$ ArcMap 8.3 and ESRI ${ }^{\odot}$ ArcView 3.2 to map each study area, design a grid, and assign catch and effort data from the fishing sets to the cells. Within each MPA, we defined the size of the cells based on an iterative process in search of a compromise between the length of fishing sets and the number of sets occurring within cells of alternative dimensions. Furthermore, the process was conducted under literature-informed constraint that the cell size should be likely to provide sufficient resolution to detect spillover. The length of fishing sets among MPAs and fishing tactics ranged from 100 to $5040 \mathrm{~m}$ with modes between 500 and $1500 \mathrm{~m}$. We drew the set trajectories on the GIS maps based on start and ending positions and created polygons around each tracing. To consider the sinuosity of each set, we maintained the surface of each polygon proportional to the real length of the set (i.e. meters of gear deployed). The cell size selection process resulted in cells ranging from $150 \times 150 \mathrm{~m}$ in Medes to $750 \times 750 \mathrm{~m}$ in Cabo de Palos (Table 3 ). The total number of cells in which fishing sets occurred varied from 18 for Cabo de Palos lobster to 366 for Medes mullet tactics.

We assigned effort and catch from each fishing set to corresponding cells based on the overlay of polygons representing each set and the cells in each map, and allocated effort and catch per set to cells in proportion to the area of the corresponding polygon falling within each cell. For each fishing tactic we calculated effort density, CPUA and revenue by cell. Effort density was calculated as the sum of the number of hooks or meters of net, CPUA as the sum of the number of fish caught and retained, and revenue as the sum of the value of the retained catch in each cell. Mean effort density and CPUA per cell in the sparid and grouper long-line 

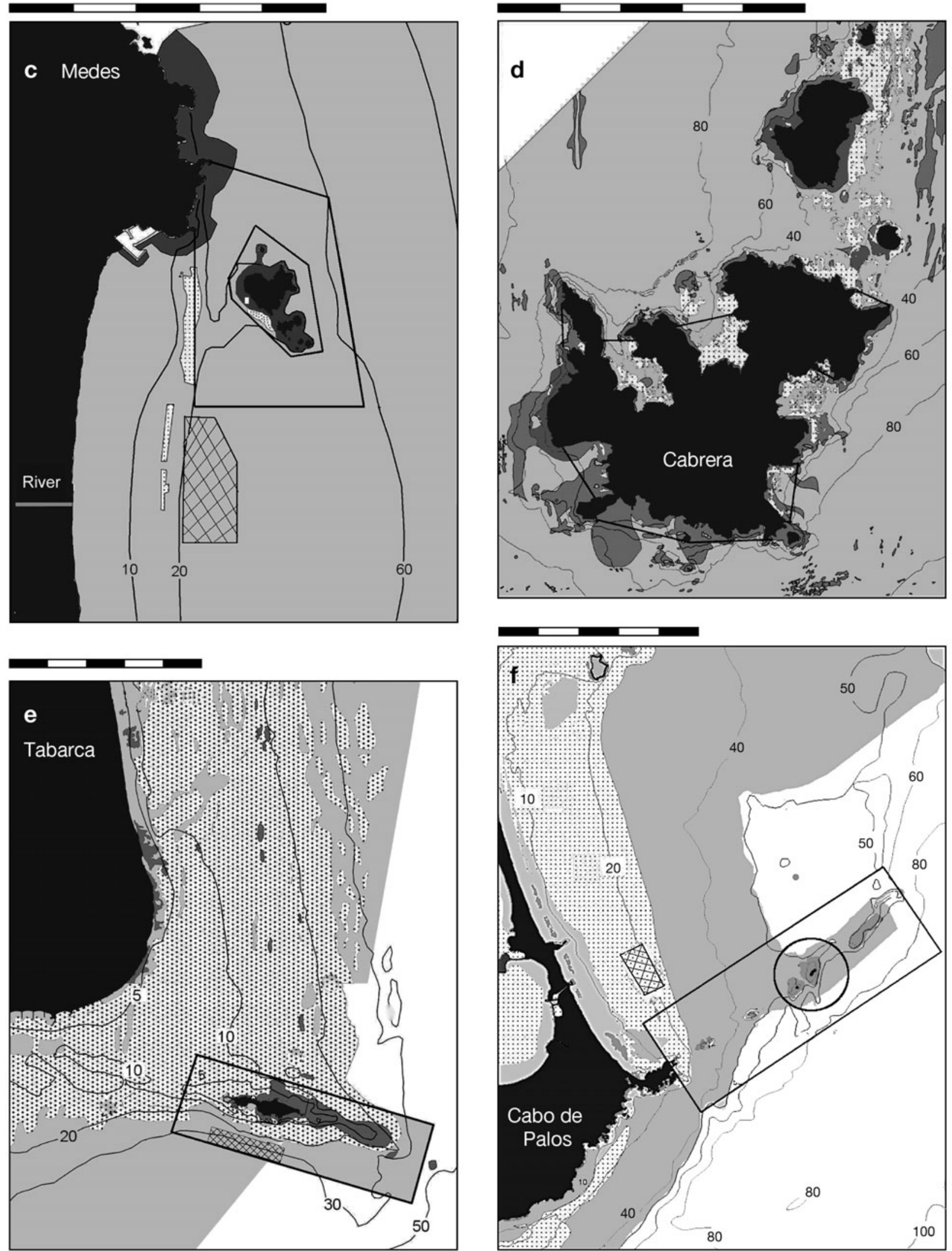

Fig. 2 (continued) 
tactics ranged from 198 to 1065 hooks $\mathrm{km}^{-2}$ and 15 to 88 fish $\mathrm{km}^{-2}$, in the sparid gill net tactics from 1530 to $6006 \mathrm{~m}$ of net $\mathrm{km}^{-2}$ and 39 to 962 fish $\mathrm{km}^{-2}$, in the rockfish and lobster tactics from 1680 to $3595 \mathrm{~m}$ of net $\mathrm{km}^{-2}$ and 7 to 105 individuals $\mathrm{km}^{-2}$ and in the mullet tactics from 1602 to $5810 \mathrm{~m}$ of net $\mathrm{km}^{-2}$ and 210 to 1112 fish $\mathrm{km}^{-2}$ by cell.

The distance from the fished cells to the FC areas was measured by a straight line from the midpoint of each cell to the nearest FC boundary. For cells that crossed the FC boundary, distance was measured from the midpoint of the portion of the cell outside the FC. The maximum distance ranged from $1623 \mathrm{~m}$ for sparid and grouper tactics in Cabrera to $15690 \mathrm{~m}$ for sparid tactics in Tabarca. Depth was estimated from bathymetric maps and ranged from $5 \mathrm{~m}$ for the Carry mullet tactic to $100 \mathrm{~m}$ for the Cabrera sparid long-line tactic.

Data analysis. To investigate the spatial distribution of effort and catches we used a regression approach and explored the relationships of the following response variables: (1) effort density by cell (in meters of net or number of hooks per $\mathrm{km}^{2}$ ), (2) CPUA by cell (in number of fish caught and retained per $\mathrm{km}^{2}$ ), and (3) revenue by cell (in monetary value [€] of the CPUA per $\mathrm{km}^{2}$ ) with the explanatory variables (1) distance from the cell to the FC, and (2) mean depth of the cell. We introduced depth as a predictor variable to account for the potential effect of bathymetry on the distribution of species in the catch. First, as an exploratory tool, we used generalized additive models (GAMs, Hastie \& Tibshirani 1990), as we expected relationships to be non-linear and this non-parametric technique allows

Table 3. Size of square cells in each marine protected area (MPA) and number of cells used in generalized linear models of effort density and catch per unit area with distance to fishery closures (FC) and depth by fishing tactic. Distance $=$ distance from cell to nearest protection boundary (i.e. restricted use area boundary for Tabarca and FC boundary for other MPAs), depth = mean depth of cell, 'combined' tactics = gill net and trammel net

\begin{tabular}{|c|c|c|c|c|c|}
\hline MPA & $\begin{array}{l}\text { Cell side } \\
\quad(\mathrm{m})\end{array}$ & Fishing tactic & $\begin{array}{l}\text { No. of } \\
\text { cells }\end{array}$ & $\begin{array}{l}\text { Distance } \\
\text { range }(\mathrm{m})\end{array}$ & $\begin{array}{l}\text { Depth } \\
\text { range }(\mathrm{m})\end{array}$ \\
\hline Carry & 250 & $\begin{array}{l}\text { Sparids combined } \\
\text { Mullet trammel net }\end{array}$ & $\begin{array}{l}34 \\
45\end{array}$ & $\begin{array}{c}40-995 \\
5-998\end{array}$ & $\begin{array}{l}5-50 \\
5-50\end{array}$ \\
\hline Banyuls & 300 & $\begin{array}{l}\text { Sparids combined } \\
\text { Lobster trammel net }\end{array}$ & $\begin{array}{l}17 \\
15\end{array}$ & $\begin{array}{l}128-869 \\
141-810\end{array}$ & $\begin{array}{l}12-65 \\
22-65\end{array}$ \\
\hline Medes & 150 & $\begin{array}{l}\text { Sparids gill net } \\
\text { Mullet trammel net }\end{array}$ & $\begin{array}{c}81 \\
136\end{array}$ & $\begin{array}{c}14-800 \\
500-2497\end{array}$ & $\begin{array}{l}10-60 \\
10-35\end{array}$ \\
\hline Cabrera & 250 & $\begin{array}{l}\text { Grouper long-line } \\
\text { Sparids long-line } \\
\text { Rockfish trammel net }\end{array}$ & $\begin{array}{l}91 \\
38 \\
66\end{array}$ & $\begin{array}{c}20-1623 \\
712-1623 \\
40-1623\end{array}$ & $\begin{array}{l}20-90 \\
20-100 \\
20-90\end{array}$ \\
\hline Tabarca & 550 & $\begin{array}{l}\text { Sparids long-line } \\
\text { Sparids gill net } \\
\text { Mullet trammel net }\end{array}$ & $\begin{array}{l}12 \\
17 \\
18\end{array}$ & $\begin{array}{l}259-2490 \\
272-1922 \\
270-3200\end{array}$ & $\begin{array}{l}15-60 \\
10-30 \\
20-60\end{array}$ \\
\hline $\begin{array}{l}\text { Cabo de } \\
\text { Palos }\end{array}$ & 750 & $\begin{array}{l}\text { Rockfish trammel net } \\
\text { Lobster trammel net }\end{array}$ & $\begin{array}{c}21 \\
7\end{array}$ & $\begin{array}{c}229-1490 \\
0-673\end{array}$ & $\begin{array}{l}10-75 \\
10-80\end{array}$ \\
\hline
\end{tabular}

exploration of trends without constraining their shape. Distance and depth were introduced in the linear predictor as non-parametric smoothers with 4 degrees of freedom (df). For distances greater than $2000 \mathrm{~m}$ we added 1 degree of freedom every $1000 \mathrm{~m}$. We determined appropriate probability distributions to implement the models by regressing the logarithm of the mean of each response variable in $200 \mathrm{~m}$ distance intervals, and the logarithm of the variance. For all fishing tactics and response variables the variance was closely proportional to the square of the mean; accordingly we used a gamma probability distribution. To relate the response variables to the linear predictor we selected the logarithmic link. To evaluate model fits we inspected the distribution of model deviance and residuals. Next, based on inspection and interpretation of GAM outputs for effort density and CPUA, we selected data for each fishing tactic within particular distances to FC boundaries and implemented generalized linear models (GLMs, McCullagh \& Nelder 1989). Data selection was based on observing changes in slopes from trends away from FC boundaries; we used expert judgment rather than an objective criterion to define transition points. GLMs were implemented to estimate slopes and test the significance of linear relationships of effort density and CPUA with distance. The GLM linear predictors included distance to FC boundaries and depth. We used gamma and logarithmic link functions as for the GAM analyses. To evaluate the significance of each covariate, we performed analysis of deviance and tested each variable by comparing full models with models excluding the tested variable. Within the analysis of deviance we tested the linearity of the depth covariate and introduced the term as a polynomial where appropriate. Tests were performed at the $95 \%$ confidence level. The GAM and GLM analyses were implemented using the $\operatorname{gam}(x)$ and $g \operatorname{lm}(x)$ functions in S-Plus (Becker et al. 1988).

\section{RESULTS}

\section{GAMs: Patterns of effort density, CPUA, and revenues adjacent to FC areas}

Patterns of effort density and CPUA with distance to FCs were non linear with a general tendency to decline near boundaries (Figs. 3 to 8). The exception was the sparid long-line tactic in Cabrera, for which effort and CPUA were 
initially stable and then declined (Fig. 6). The extent of effort density and CPUA gradients adjacent to FC areas among MPAs was 800 to $2490 \mathrm{~m}$ from FC boundaries for all sparid tactics, 998 to $3200 \mathrm{~m}$ for mullet tactics, 673 to $810 \mathrm{~m}$ for lobster tactics, and 1490 to $1623 \mathrm{~m}$ for rockfish and grouper tactics (Figs. 3 to 8). As distance from FC areas increased, effort and CPUA trends presented secondary peaks in the Carry (Fig. 3) and Medes (Fig. 5) sparid tactics and all the Banyuls (Fig. 4) and Tabarca (Fig. 7) tactics. Adjacent to FC boundaries, revenues followed the same trends as CPUA except for the Banyuls sparid (Fig. 4), Medes mullet (Fig. 5), Cabrera sparid and rockfish (Fig. 6) and Tabarca sparid long-line (Fig. 7) tactics. In these cases, revenues remained stable near boundaries while effort and CPUA declined. Based on the GAM patterns observed we selected data from cells within 673 to $3200 \mathrm{~m}$ from FC boundaries, depending on the MPA and fishing tactic, to run GLMs and estimate slopes of effort density and CPUA with distance to FCs (Table 3).
Effort, CPUA, and revenues were stable with depth within ranges fished by most fishing tactics (e.g. Fig. 3). Exceptions were the Carry sparid (Fig. 3a), Cabrera grouper and Cabo de Palos lobster tactics, in which effort, CPUA, and revenues peaked at intermediate depths, and the Cabrera rockfish tactic in which effort, CPUA and revenues were initially stable and declined in deeper waters (not shown).

\section{GLMs: Gradients of effort density and CPUA as a function of distance to FC boundaries}

Slopes of linear regressions of fishing effort density as a function of distance to FC boundaries for the 14 fishing tactics analyzed were negative and significant except for the Tabarca mullet trammel net tactic (Table 4). Slopes of regressions for CPUA with distance from the FC boundaries were also negative for the 14 fishing tactics analyzed and 9 were significant (a) Carry: Sparids
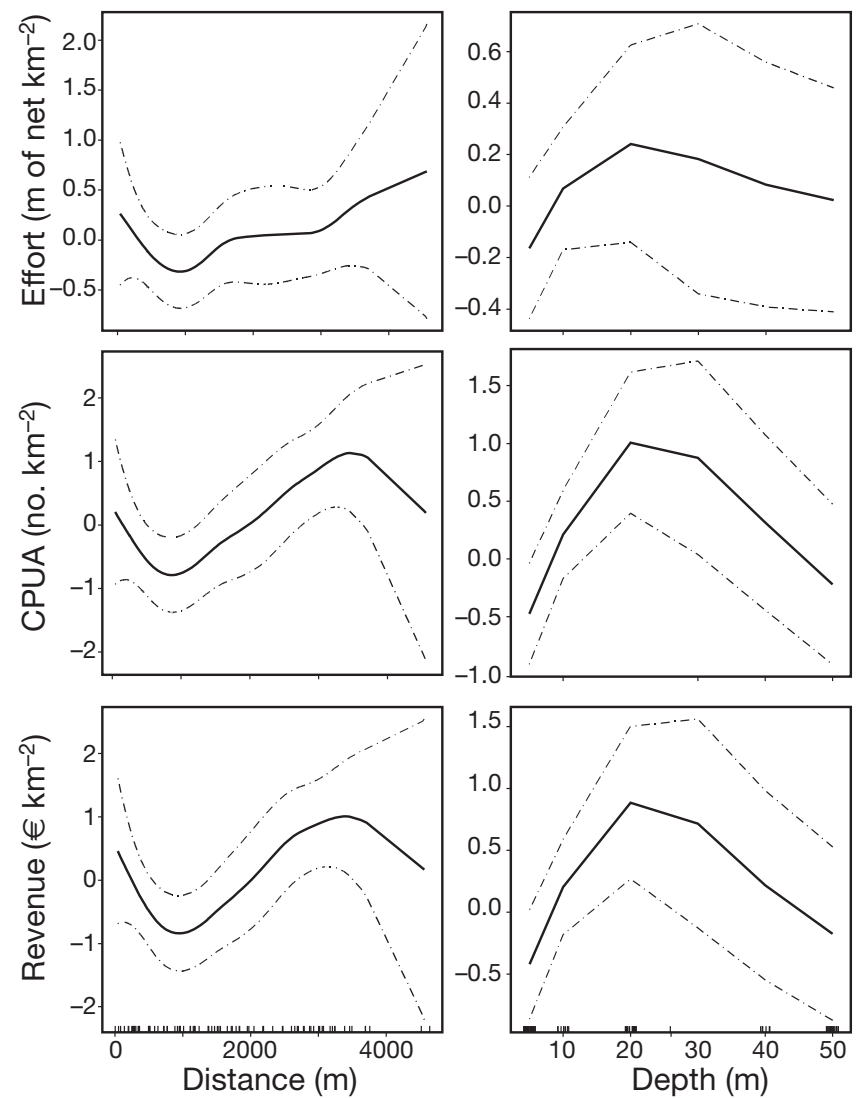

(b) Carry: Mullet
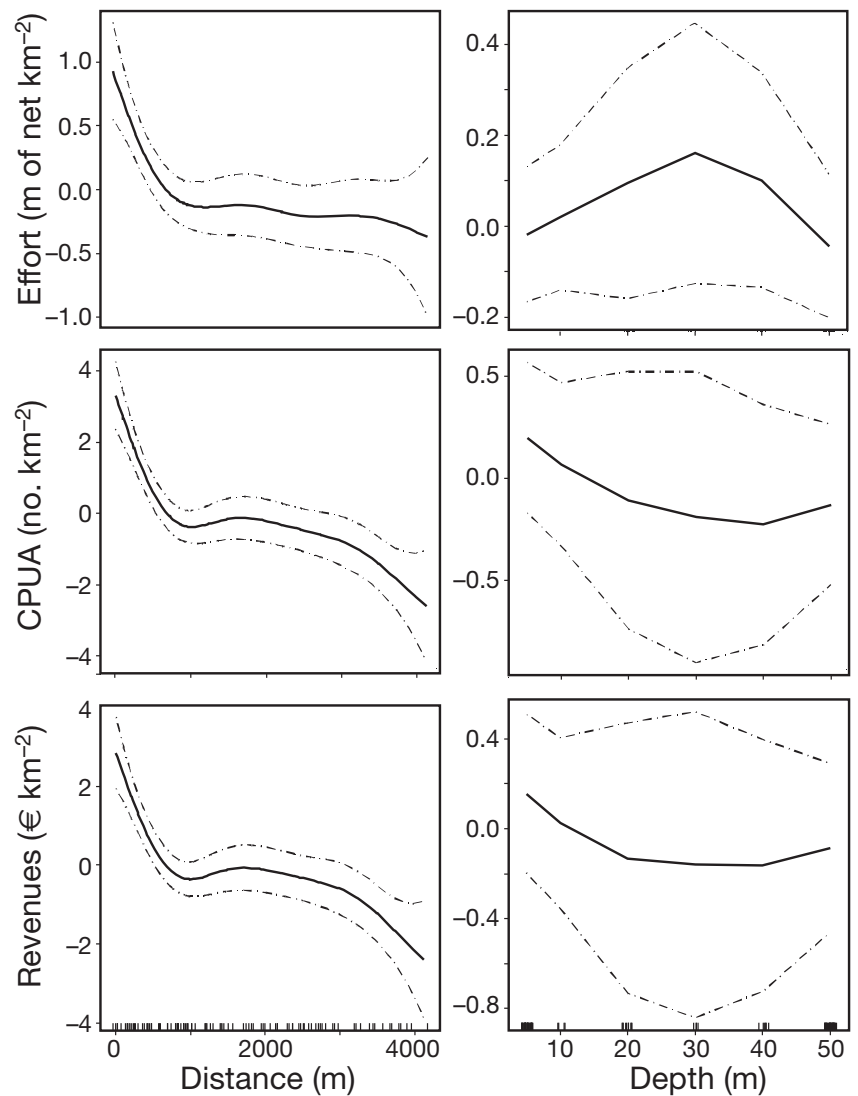

Fig. 3. Generalized additive model (GAM) predicted values by cell for effort ( $\mathrm{m}$ of net $\mathrm{km}^{-2}$ ), catch per unit area $\left(\mathrm{CPUA}\right.$, no. $\mathrm{km}^{-2}$ ), and revenues ( $€ \mathrm{~km}^{-2}$ ) within Carry-le-Rouet for (a) sparid and (b) mullet fishing tactics. Models incorporate the predictors 'distance to fisheries closure boundaries' and 'depth' as nonparametric smoothers, and gamma variance and logarithmic link functions. $y$-axes are standardized so that $y=0$ represents the mean response. Bands around the predictions are approximate $95 \%$ confidence envelopes. Rug plot on the $x$-axis represents amount of data available 


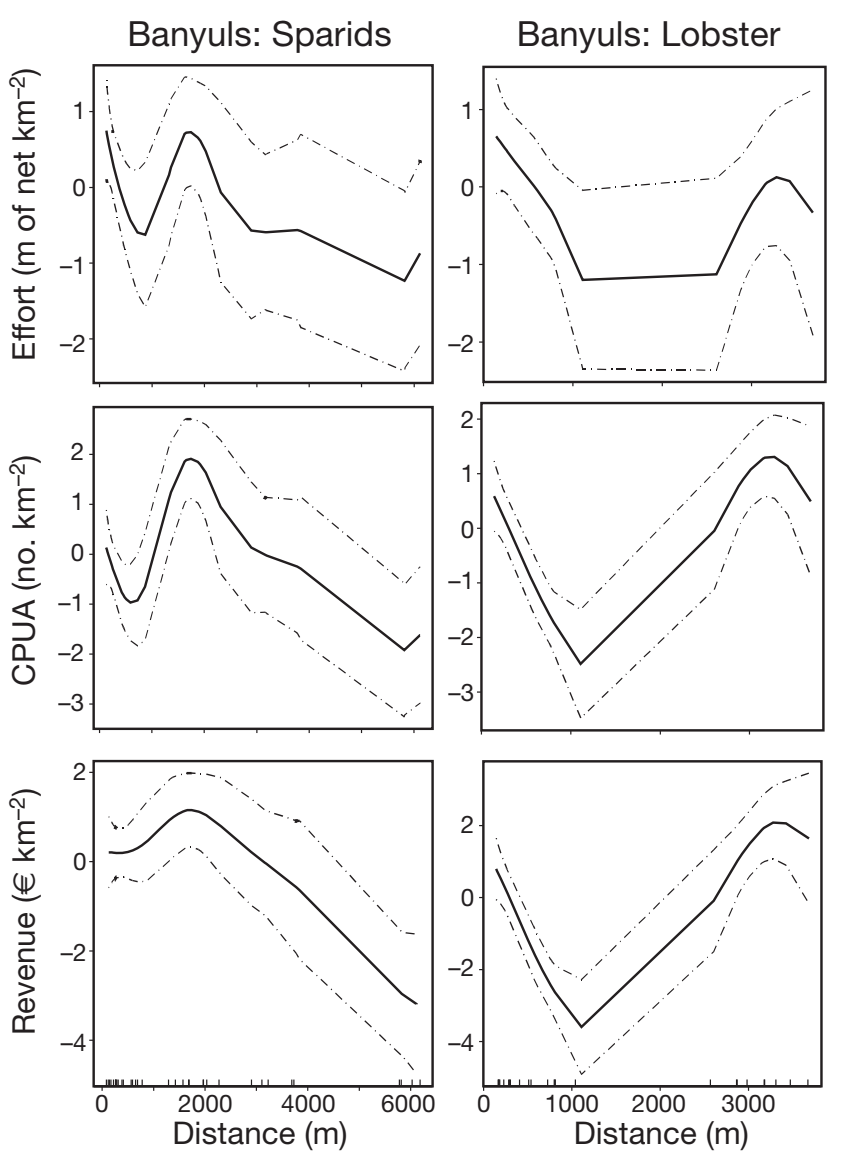

Fig. 4. GAM predicted values by cell for effort $\left(\mathrm{m}\right.$ of net $\left.\mathrm{km}^{-2}\right)$, catch per unit area (CPUA, no. $\left.\mathrm{km}^{-2}\right)$, and revenues $\left(€ \mathrm{~km}^{-2}\right)$ within Banyuls sparid and lobster fishing tactics. Other details as in Fig. 3

(Table 4). Exceptions were the 3 Cabrera tactics ( $p>$ $0.06)$, the Tabarca mullet $(p>0.1)$ and the Cabo de Palos rockfish $(\mathrm{p}>0.4)$ tactics (Table 4). Significant negative slopes of effort density and CPUA were steepest in the lobster tactic in Cabo de Palos and shallowest in the Cabrera rockfish and Medes mullet tactics (Table 4).

Effort density varied significantly with depth in the 3 fishing tactics in Cabrera and the rockfish tactic in Cabo de Palos $(p<0.04)$. CPUA varied significantly with depth in the grouper and rockfish tactics in Cabrera $(\mathrm{p}<0.04)$. When significant, the relationship between effort density or CPUA and depth was nonlinear, characterized by initial stable levels followed by a decrease, and best represented by a second degree polynomial. The effects of depth and distance were not correlated in the models for effort or CPUA, as the decrease with depth occurred after the decrease with distance was observed at several hundred meters away from FC boundaries.
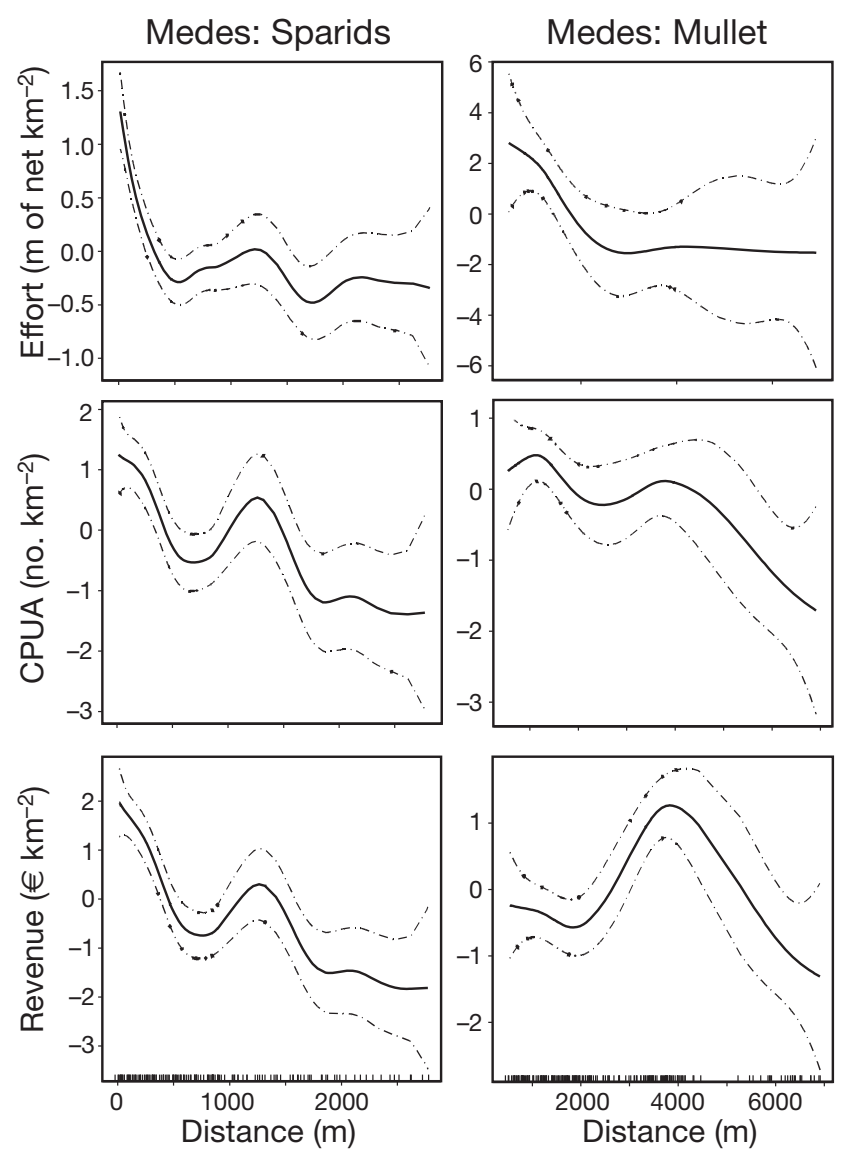

Fig. 5. GAM predicted values by cell for effort ( $\mathrm{m}$ of net $\mathrm{km}^{-2}$ ), catch per unit area (CPUA, no. $\left.\mathrm{km}^{-2}\right)$, and revenues ( $€ \mathrm{~km}^{-2}$ ) within Medes sparid and mullet fishing tactics. Other details as in Fig. 3

\section{DISCUSSION}

In our study of 6 Western Mediterranean MPAs, concentration of fishing effort found near FC boundaries can be interpreted as spillover benefits to adjacent fisheries. Fishing effort was highest near the FC boundaries for all 14 fishing tactics in the 6 MPAs studied and declined significantly in all but the mullet trammel net tactic in Tabarca. Where observed, this pattern of 'edge fishing' or 'fishing the line' around MPAs has been taken as a clear indication of spillover (e.g. Yamasaki \& Kuwahara 1989, McClanahan \& Mangi 2000, Kelly et al. 2002, Willis et al. 2003, Murawski et al. 2005, Goñi et al. 2006), although effort aggregation can also result from redistribution of effort after MPA creation (Halpern et al. 2004, Murawski et al. 2005), or from perceived benefits leading fishers to occupy fishing spots along boundaries even when yields become locally depleted (McClanahan \& Kaunda-Arara 1996, McClanahan \& Mangi 2000, Willis et al. 2003). In the case of well established MPAs such as 

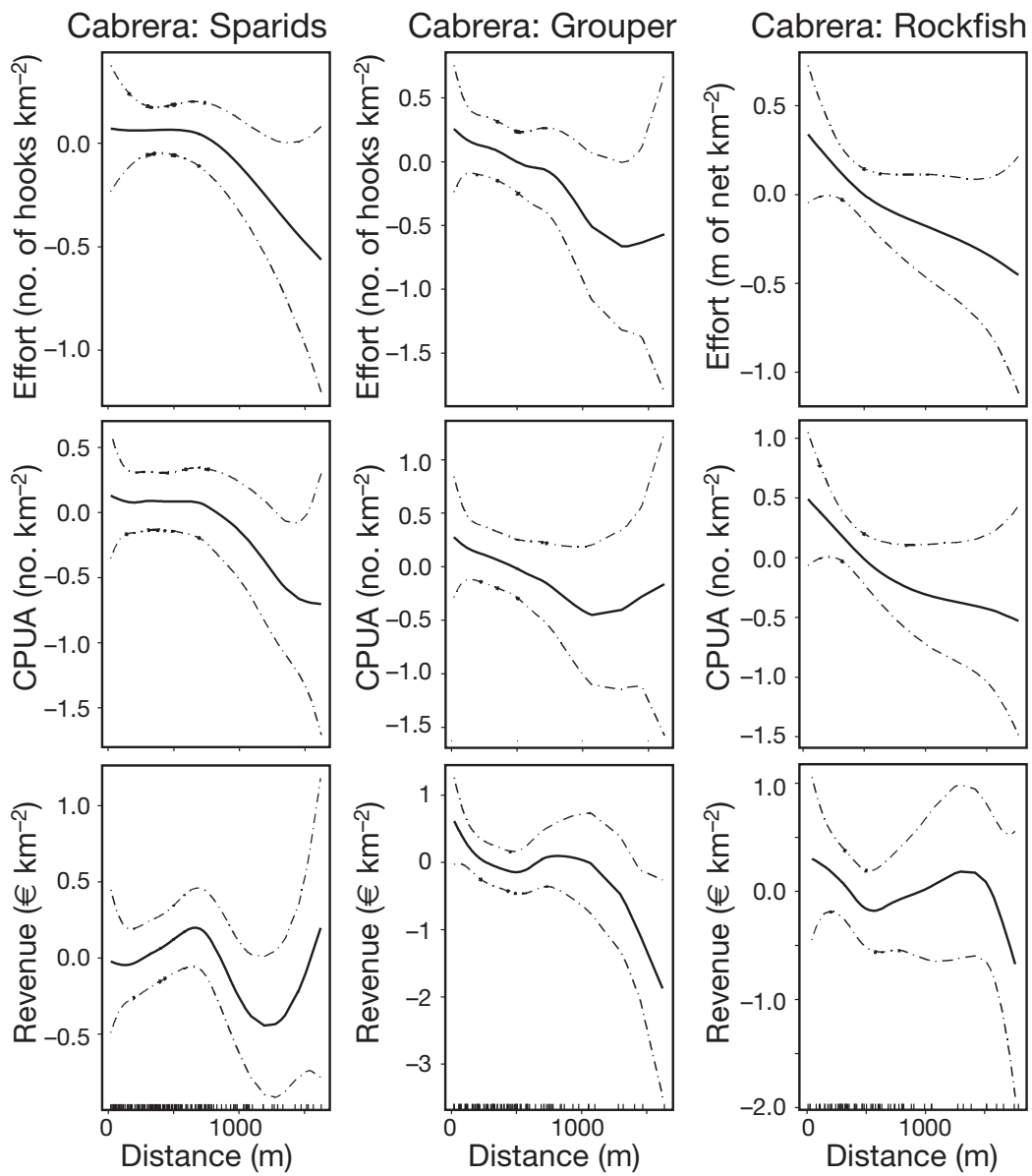

those in this study we can safely assume that observed effort distribution responded to achieved fishery benefits, as predicted by MPA fishery models (Maury \& Gascuel 1999, Kellner et al. 2007). Aggregation of effort near MPA boundaries is not always observed when effective protection takes place. Such cases have been reported when the cost from traveling from home ports to MPAs is high (Wilcox \& Pomeroy 2003), or when greater yield variability near MPAs attenuates spillover benefits (Abesamis et al. 2006a). Furthermore, MPA boundaries may not attract fishers when there are productive fishing grounds nearby (Abesamis et al. 2006a). In our study, effort aggregation near FC boundaries occurred even when productive fishing grounds were found in the vicinity of several MPAs, as revealed by secondary effort density peaks in GAM plots. Only for the mullet trammel net tactic in Tabarca, important fishing grounds located about $7 \mathrm{~km}$ north of the MPA (Figs. 1 \& 7) may have detracted effort from the MPA boundaries.

Trends in fishery production in this study declined with distance from FC boundaries and are generally consistent with reported build-up of exploited species in the study MPAs. CPUA was

Fig. 6. GAM predicted values by cell for effort (no. of hooks or $\mathrm{m}$ of net $\mathrm{km}^{-2}$ ), catch per unit area (CPUA, no. $\left.\mathrm{km}^{-2}\right)$, and revenues $\left(€ \mathrm{~km}^{-2}\right)$ within Cabrera sparid long-line, grouper long-line, and rockfish trammel net tactics. Other details as in Fig. 3

Table 4. Slopes of effort density and retained catch by area (CPUA) as a function of distance to fishing closure (FC) boundaries from generalized linear models incorporating distance and depth. Distance was to restricted use area boundary for Tabarca and to FC boundary for other MPAs. Models included a gamma distribution and a logarithmic link. $95 \%$ CI are confidence intervals. *indicates significant slopes at the $95 \%$ level. Combined tactics are gill net and trammel net

\begin{tabular}{|c|c|c|c|c|c|c|c|}
\hline \multirow{2}{*}{ MPA } & \multirow[t]{2}{*}{ Fishing tactic } & \multicolumn{3}{|c|}{ - Effort density } & \multirow{2}{*}{ Slope } & CPUA- & \multirow[b]{2}{*}{ Prob. of $F$} \\
\hline & & Slope & $05 \% / C \mathrm{~T}$ & Prob. of $F$ & & $95 \% \mathrm{CI}$ & \\
\hline Carry & $\begin{array}{l}\text { Sparids combined } \\
\text { Mullet trammel net }\end{array}$ & $\begin{array}{l}-0.0011 \\
-0.0012\end{array}$ & $\begin{array}{l}-0.002,-0.0002 \\
-0.002,-0.0004\end{array}$ & $\begin{array}{l}0.0076^{*} \\
0.0019^{*}\end{array}$ & $\begin{array}{l}-0.0018 \\
-0.0052\end{array}$ & $\begin{array}{l}-0.0034,-0.0002 \\
-0.0069,-0.0035\end{array}$ & $\begin{array}{l}0.0221^{*} \\
0.0001^{*}\end{array}$ \\
\hline Banyuls & $\begin{array}{l}\text { Sparids combined } \\
\text { lobster trammel net }\end{array}$ & $\begin{array}{l}-0.0034 \\
-0.0014\end{array}$ & $\begin{array}{l}-0.0055,-0.0013 \\
-0.0027,-0.0001\end{array}$ & $\begin{array}{l}0.0012^{*} \\
0.0503^{*}\end{array}$ & $\begin{array}{l}-0.0027 \\
-0.0037\end{array}$ & $\begin{array}{l}-0.0052,-0.0002 \\
-0.0059,-0.0015\end{array}$ & $\begin{array}{l}0.0238^{*} \\
0.0001^{*}\end{array}$ \\
\hline Medes & $\begin{array}{l}\text { Sparids gill net } \\
\text { Mullet trammel net }\end{array}$ & $\begin{array}{l}-0.0018 \\
-0.0005\end{array}$ & $\begin{array}{l}-0.0026,-0.001 \\
-0.0007,-0.0003\end{array}$ & $\begin{array}{l}0.0001^{*} \\
0.0009^{*}\end{array}$ & $\begin{array}{l}-0.0026 \\
-00007\end{array}$ & $\begin{array}{l}-0.0037,-0.0015 \\
-0.0013,-0.0001\end{array}$ & $\begin{array}{l}0.0001^{*} \\
0.0399^{*}\end{array}$ \\
\hline Cabrera & $\begin{array}{l}\text { Grouper long-line } \\
\text { Sparids long-line } \\
\text { Rockfish trammel net }\end{array}$ & $\begin{array}{l}-0.0006 \\
-0.0017 \\
-0.0004\end{array}$ & $\begin{array}{l}-0.0009,-0.0003 \\
-0.0033,-0.0001 \\
-0.0007,-0.0001\end{array}$ & $\begin{array}{l}0.0089^{*} \\
0.0059^{*} \\
0.0329^{*}\end{array}$ & $\begin{array}{l}-0.0004 \\
-0.0012 \\
-0.0004\end{array}$ & $\begin{array}{ll}-0.0008, & 0.0000 \\
-0.0027, & 0.0003 \\
-0.0009, & 0.0001\end{array}$ & $\begin{array}{l}0.0635 \\
0.0697 \\
0.1172\end{array}$ \\
\hline Tabarca & $\begin{array}{l}\text { Sparids long-line } \\
\text { Sparids gill net } \\
\text { Mullet trammel net }\end{array}$ & $\begin{array}{l}-0.0017 \\
-0.0011 \\
-0.0002\end{array}$ & $\begin{array}{l}-0.003, \quad-0.0004 \\
-0.0015,-0.0007 \\
-0.0006, \quad 0.0002\end{array}$ & $\begin{array}{l}0.0114^{*} \\
0.0123^{*} \\
0.1849\end{array}$ & $\begin{array}{l}-0.0014 \\
-0.0008 \\
-0.0002\end{array}$ & $\begin{array}{lr}-0.002, & -0.0008 \\
-0.0001, & -0.0015 \\
-0.0006, & 0.0002\end{array}$ & $\begin{array}{l}0.0015^{*} \\
0.0451^{*} \\
0.1561\end{array}$ \\
\hline Cabo de Palos & $\begin{array}{l}\text { Rockfish trammel net } \\
\text { Lobster trammel net }\end{array}$ & $\begin{array}{l}-0.0011 \\
-0.0071\end{array}$ & $\begin{array}{l}-0.0017,-0.0005 \\
-0.017,-0.0035\end{array}$ & $\begin{array}{l}0.0036^{*} \\
0.0027^{*}\end{array}$ & $\begin{array}{l}-0.0001 \\
-0.0077\end{array}$ & $\begin{array}{rr}-0.0018, & 0.0017 \\
-0.0118, & -0.0036\end{array}$ & $\begin{array}{l}0.4881 \\
0.0017^{*}\end{array}$ \\
\hline
\end{tabular}



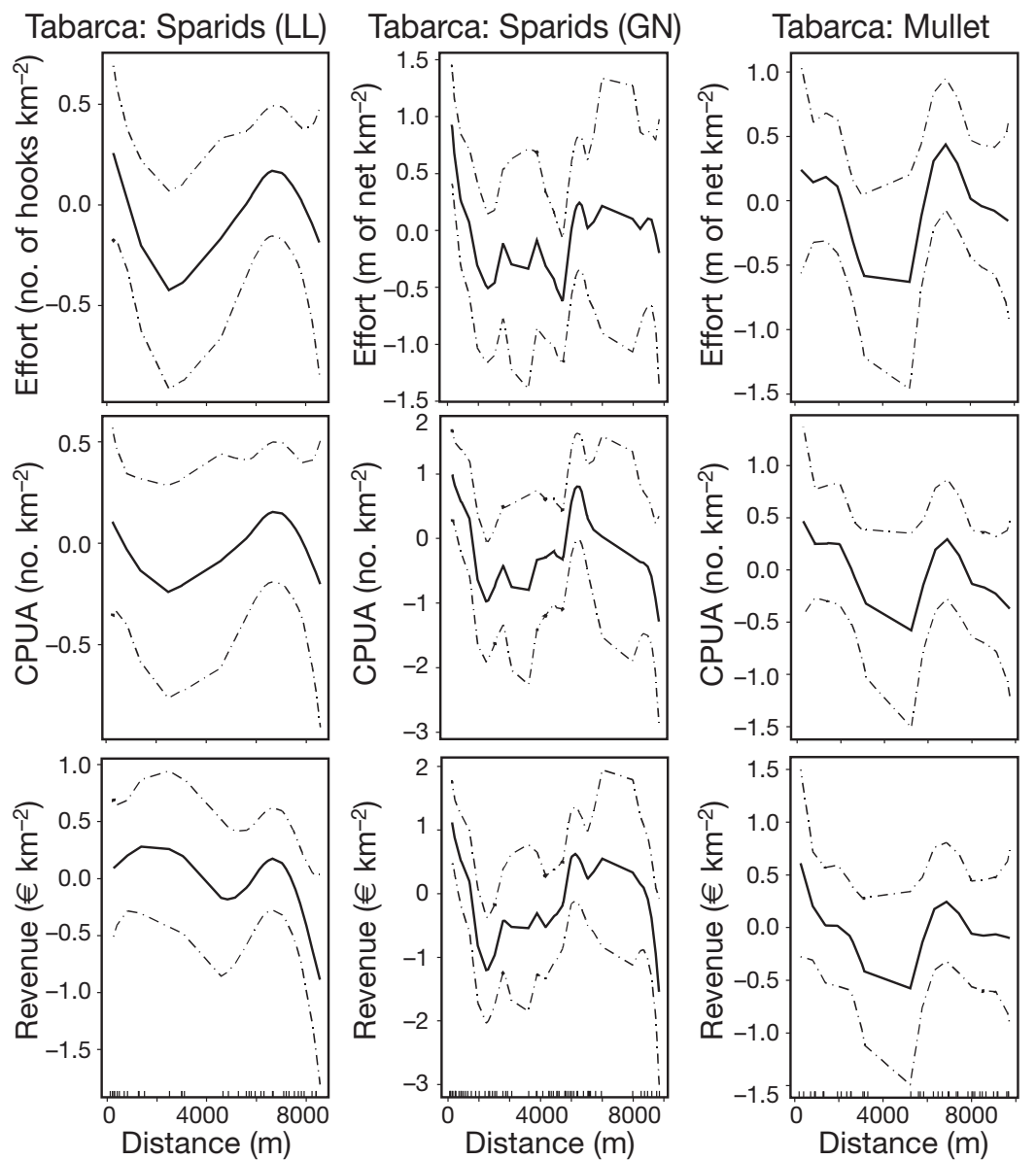

Fig. 7. GAM predicted values by cell for effort (no. of hooks or $\mathrm{m}$ of net $\mathrm{km}^{-2}$ ), catch per unit area (CPUA, no. $\left.\mathrm{km}^{-2}\right)$, and revenues $\left(€ \mathrm{~km}^{-2}\right)$ within Tabarca sparid long-line (LL) and gillnet (GN) and mullet fishing tactics. Other details as in Fig. 3

highest near FC boundaries for all 14 fishing tactics, and in 9 of the cases negative slopes away from boundaries were significant. Exceptions were the 3 tactics in Cabrera, and the Tabarca mullet and Cabo de Palos rockfish tactics. Build-up of exploited species in MPAs in this study is well documented (e.g. García-Rubies 1997, Sánchez-Lizaso et al. 2000, García-Charton et al. 2004, Ojeda-Martinez et al. 2007) and contemporary underwater visual census (UVC) of fish density indicated declining gradients from inside FCs to the adjacent fishing areas of sparids (Diplodus spp., Sparus aurata, Dentex dentex, Pagrus pagrus, Spondyliosoma cantharus), serranids (Epinephelus spp., Serranus spp.), labrids (Labrus spp., Symphodus spp.), scorpaenids (Scorpaena scrofa), muraenids (Muraena helena), and congrids (Conger conger) (Planes 2005). These are the main species caught by fishing tactics in this study and thus, our findings support the biomass export hypotheses in particular for the sparids tactics (Table 2). Other species were not assessed by
UVC due to their behavior (e.g. Pagellus spp., Scyliorhinus canicula) or cryptic nature (e.g. Scorpaena porcus). In tactics where these species are important, in particular in the Medes sparid tactic, the lack of UVC evidence makes it difficult to assess how production gradients relate to population build-up. Evidence from UVC on species caught in all 3 tactics in Cabrera indicates density buildup in the FCs and thus biomass export could have been affected by habitat characteristics or by methodological factors also related to habitat. The only species reported to be more abundant outside than within FC boundaries was Mullus surmuletus in Medes (Planes 2005), where the species is targeted by the trammel net fishing tactic.

Fishery production gradients in our study were generally consistent with expected MPA benefits based on behaviour of species in the catch and fishery exploitation. Spillover benefits are expected from MPAs for species that exhibit moderate movements and that are highly exploited when species are protected in habitats with continuity in adjacent areas (Kramer \& Chapman 1999, Tewfik \& Bene 2003, Tupper 2007). Habitat continuity should not be an obstacle for biomass export in our study as we selected tactics among MPAs that target species for which suitable surroundings were present to varying degrees in all the FCs and adjacent fished areas. These habitats are coastal rocky and mixed substrates for sparids, scorpeanids, labrids and serranids (Harmelin 1987) present in all MPAs, Posidonia meadows for Mullus surmuletus (Harmelin 1987) abundant in Carry and Tabarca and rocky and coralligenous habitats for Palinurus elephas and associated species (Goñi \& Latrouite 2005) present in Banyuls and Cabo de Palos. Trends were generally significant among fishing tactics catching predominantly moderately vagile sparids, mullids, and palinurids, while trends were not significant in the tactics with presence of varying proportions of sedentary species, in particular scorpaenids (Table 2). Thus, significant production trends in sparids, mullet and lobster tactics are a likely indication of spillover benefits, while non-significant negative trends in rockfish tactics may suggest lesser benefits to the fisheries. The influence of fishery exploitation was not assessed in our study, but production gradients were consistent with gear efficiency. Theory predicts that when populations 


\section{Cabo de Palos: Lobster}
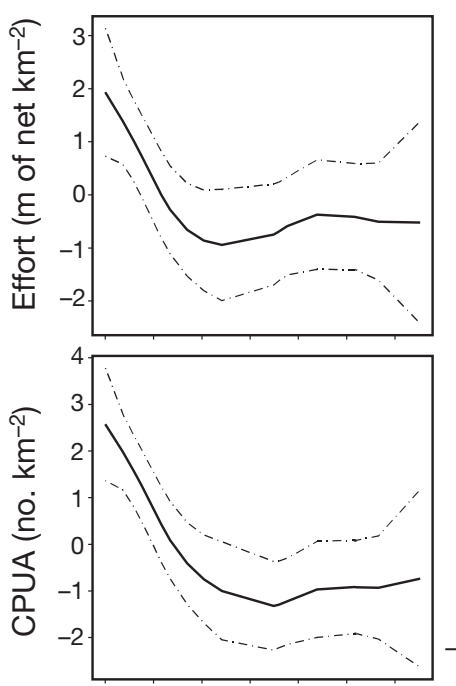

Cabo de Palos: Rockfish
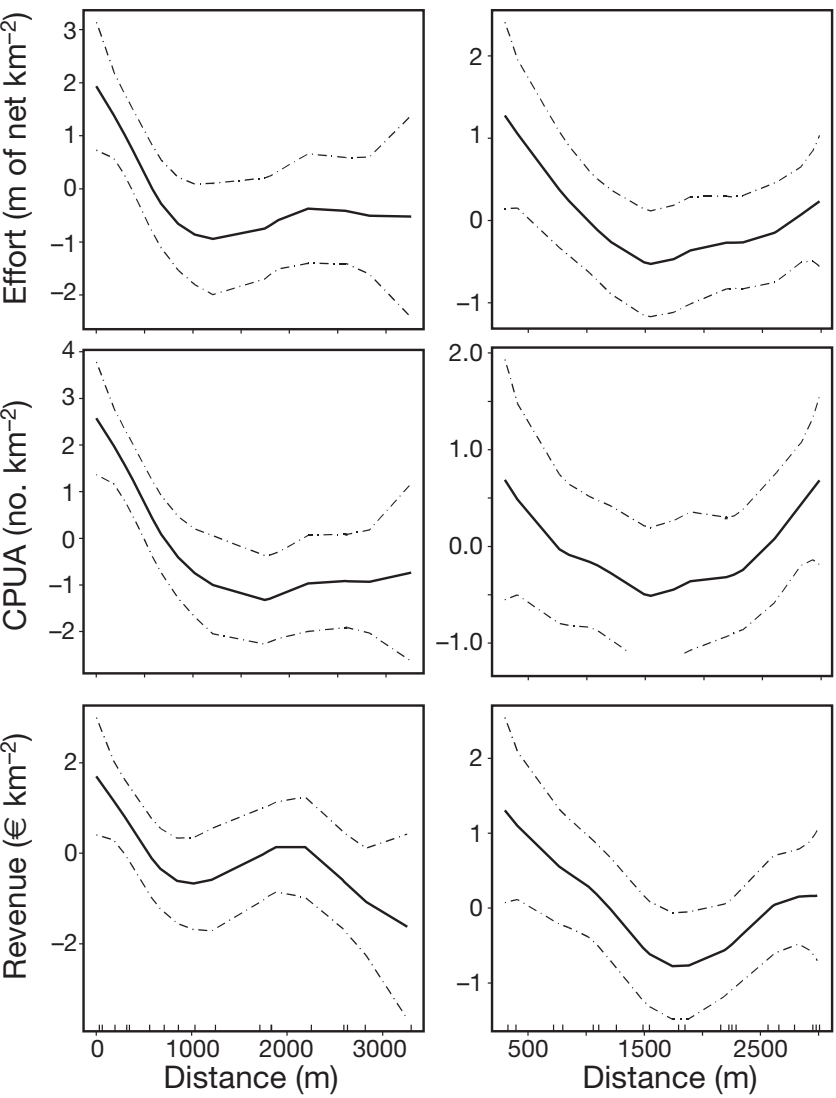

Fig. 8. GAM predicted values by cell for effort $\left(\mathrm{m}\right.$ of net $\left.\mathrm{km}^{-2}\right)$, catch per unit area (CPUA, no. $\mathrm{km}^{-2}$ ), and revenues (€ $\mathrm{km}^{-2}$ ) within Cabo de Palos rockfish and lobster fishing tactics. Other details as in Fig. 3

build up inside MPAs, density gradients away from FCs are, inter alia, a function of species catchability (Rakitin \& Kramer 1996), and magnitude of spillover effects observed in tropical MPAs have been partially attributed to the differential efficiency of fishing gears used in adjacent fisheries (McClanahan \& Mangi 2000, Abesamis et al. 2006a). In our study the Carry mullet tactic exhibited one of the steepest gradients and used trammel nets, the most efficient gear in the study. The steep production trends in the lobster tactics are also consistent with the high catchability of the target species in trammel nets (Goñi et al. 2003). On the other hand, the sparid tactics exhibited shallower production gradients, congruent with lower efficiency of gill nets and longlines that allow fish to move greater distances before being caught.

Production gradients of some tactics in this study were probably affected by characteristics of habitats within and around MPAs. Gradients in CPUA were not significant for the 3 tactics in Cabrera, and also for the Tabarca mullet and Cabo de Palos rockfish tactics, despite reported biomass build-up of the most common species in the FCs. In Cabrera, habitat characteristics pose challenges for the evaluation of benefits to fisheries based on gradients due to the spatial configuration of the FC areas, which consist of numerous bays around a main island. Regardless of general availability of suitable areas within and around FCs, the relatively secluded bays may conceal features not present in adjacent areas that may affect biomass export of some species. Further, since it was not possible to identify specific bays where individuals originated, distances measured from fishing set locations to the nearest bay might not accurately represent the distance between the protection boundary and the fishing location. As with effort, production gradients in the Tabarca mullet tactic may have been affected by the presence of productive fishing grounds $7 \mathrm{~km}$ north of the MPA. In Medes, the opposite was observed, as gradients of effort and production of the mullet tactic tested significant despite reported absence of biomass build-up of Mullus surmuletus. In this case gradients were affected by the presence of Posidonia meadows near the MPA southeast boundary which were scarce within the FC area. Thus, we do not interpret these gradients as indicative of spillover because of the reported lack of build-up and the effects of habitat on gradients.

The spatial extent of production gradients away from FC boundaries in our study is consistent with spillover effects reported for littoral and coral reef species in the Mediterranean and are low compared to reports for soft bottom temperate species. Effects ranged from about 700 to $1000 \mathrm{~m}$ in the lobster and mullet tactics, up to $2500 \mathrm{~m}$ in the sparid tactics. For the lobster tactics, the scale was similar to that for Palinurus elephas (1000 to $1500 \mathrm{~m}$; Goñi et al. 2006) from a western Mediterranean MPA. Fish density gradients from UVC observations in the MPAs in this study extended only up to $500 \mathrm{~m}$ from the boundaries of FCs (Planes 2005), but UVC likely underestimates the potential significance of fish exported to the local fisheries since only fish in excess of those caught are detected (Russ \& Alcala 1996). Gradients of CPUE away from MPAs similar to those reported in our study have been documented for related species in coral reefs (e.g. McClanahan \& Mangi 2000, Roberts et al. 2001, Galal et al. 2002, Russ et al. 2004, Abesamis \& Russ 2005, Abesamis et al. 2006b). More extensive CPUE gradients extending up to $4 \mathrm{~km}$ from MPA boundaries have been reported in the Northwest Atlantic for soft bottom groundfish species (Murawski et al. 2005), and up to $13 \mathrm{~km}$ in waters off Japan for the crab Chionoecetes opilio (Yamasaki \& Kuwahara 1989).

Fisheries revenues generally declined with distance to fisheries closures in a similar way to production but cannot be easily compared with the few studies avail- 
able, which have reported varying results. In our study, enhanced revenue gradients were expected given the greater size (and value) of many exploited species near FCs (Planes 2005). The exception was in Cabrera, where the mean size of species important in the catch of the 3 fishing tactics (sparids, e.g. Pagrus pagrus, Spondyliosoma cantharus; scorpaenids, e.g. Scorpaena scrofa) were smaller near protection boundaries due to the presence of nursery habitats in the FC areas (Planes 2005). Revenue gradients were also influenced by variation in the species composition of catches with distance to FC boundaries, as occurred in the Banyuls and Tabarca sparid tactics. In previous studies, $\mathrm{Mu}-$ rawski et al. (2005) reported higher economic yields near temperate MPAs while McClanahan \& KaundaArara (1996) observed the opposite in an MPA in Kenya; interestingly effort concentrated along boundaries in both MPAs. Kelly et al. (2002) found that economic yields of lobster near an MPA in New Zealand were similar to those in unprotected reefs (despite the lesser quality of habitat and concentration of effort near the MPA) and interpreted these results as benefits to the fishery. Finally, Abesamis et al. (2006a) reported higher but very variable economic yields near protection boundaries in the Apo reserve in the Philippines, which caused effort not to concentrate there. Thus, gradients in revenues can be independent of effort trends and may reflect particular conditions within and around MPAs.

Including non-linear terms in our analysis was instrumental to elucidate trends of fishing effort and production. In a similar study, and to avoid the confounding influence of neighboring MPAs on fishery gradients, Murawski et al. (2005) selected distances for the study upon visual examination of trends of catch and effort data. In this study GAMs helped to identify the range at which protection effects operated and recognize habitat discontinuities or 'hot spots' (areas of high production caused by particularly beneficial habitat conditions) located in the vicinity of the MPAs. Secondary peaks of effort and production away from FC boundaries were detected for several tactics. These peaks were in some cases associated with the presence of traditional fishing grounds around the MPAs. In the sparid tactics of Carry and Banyuls (Figs. 3b \& 4), these grounds corresponded with particular capes, and in the lobster tactic in Banyuls (Fig. 4) with an isolated coralligenous zone within extensive sandy bottoms. For Medes mullet (Fig. 5) and Cabo de Palos rockfish (Fig. 8) tactics, secondary peaks coincided with the presence of artificial reefs adjacent to the RU boundaries (Fig. 2). In Tabarca, secondary peaks at about $7 \mathrm{~km}$ from the MPA (Fig. 7) were associated with traditional fishing grounds around particularly heterogeneous habitats. If not detected, secondary peaks could have obscured the analysis of effort and production trends in relation to FCs.

Recreational activities around MPAs may have weakened effort and production gradients in artisanal fisheries found in our study but would not invalidate our results. Recreational fisheries are likely to compete with artisanal fisheries for biomass export benefits and might level trends of effort and production away from FCs. Hook and line recreational fisheries could have affected catches in this study because the target species are also caught by most fishing tactics studied (e.g. Serranus spp., Diplodus annularis, D. sargus, D. vulgaris, Sparus aurata, Spondyliosoma cantharus) (Harmelin et al. 1995). Also spear-fishing, very popular in the western Mediterranean (Coll et al. 2004), might compete with the sparid, grouper and rockfish tactics. Further, non-consumptive uses such as recreational diving might create conflicts and affect choice of fishing location within RU areas. In Cabo de Palos, for example, fishermen prefer to fish in the rocky shoals least frequently visited by divers (S. Polti, University of Murcia, pers. comm.). Assessing the effects of recreational activities on gradients of artisanal fisheries was beyond the scope of this study, but they should be considered in further studies of western Mediterranean MPAs. In our study, recreational fisheries should not invalidate conclusions of spillover but could have lessened the magnitude of the observed effects.

This study highlights the complexities of analyzing biomass export from artisanal fisheries but benefits from a design that included multiple MPAs and fisheries. Studies of MPA effects are often limited by the lack of baseline data and management replication, but lack of replication was alleviated here by the implementation of the same sampling design in 6 MPAs within the same region. Despite differences among the MPAs studied here, their resemblances are underscored by the similarity of the fisheries operating around them. We conclude that concentration of fishing effort and significant negative gradients of fishery production from artisanal fisheries in the study can be best explained by processes of spillover. Our interpretation is backed up by UVC studies in the same MPAs which reported higher biomass of the main species caught in fisheries inside MPAs than in fished areas in all 6 MPAs studied (Planes 2005). The spatial extent of spillover effects was consistent with species mobility and fisheries efficiency. Production gradients were not significant when characteristics of habitat or environmental conditions within and around MPAs imposed challenges for trend evaluation. These conclusions are strengthened by the composite findings of the several cases studied.

Our results suggest that coastal MPAs can be an effective management tool for artisanal fisheries in the 
region and can be extended to the rest of the western Mediterranean, as the fishing tactics studied are typical of the region and represent an important component of the total fishing activities (Alarcón 2001, Colloca et al. 2004). Consistent with conditions identified for MPAs to benefit fishing yields (Hilborn et. al 2004), these fisheries target multispecies complexes dominated by species of restricted mobility. This study is a step forward in evaluating the effects of fishing closures in Mediterranean fisheries.

Acknowledgements. We are grateful to the skippers and crews of the artisanal vessels that voluntarily collaborated with this study and made it possible, as well as the local fisher associations and the MPA authorities that facilitated data collection. We owe thanks to Jorge Baro and Jose Miguel Serna from the Centro Oceanográfico de Malaga that designed the BIOMEX fisheries database and contributed to training on artisanal fisheries sampling. We acknowledge the invaluable help of M. Valls collecting data onboard the artisanal fleet in the Cabrera National Park, A. Delauney, M. Capoulade and K. Kawahara for field work in Carry Le Rouet, M. Sacanell for onboard sampling in the Medes Islands study, and C. Marcos and O. Esparza for their help with cartography and project management in the study of Cabo de Palos. We thank also M.C. Iglesias for editorial work. Aitor Forcada was supported by FPI grant of the Generalitat Valenciana (CTBPRB/2003/ 146). This study was funded by the EU FP VI research grant for the project BIOMEX (QLRT-2001-0891).

\section{LITERATURE CITED}

Abesamis RA, Russ GR (2005) Density-dependent spillover from a marine reserve: long-term evidence. Ecol Appl 15: $1798-1812$

Abesamis RA, Alcala AC, Russ GR (2006a) How much does the fishery at Apo Island benefit from spillover of adult fish from the adjacent marine reserve. Fish Bull (Wash DC) 104:360-375

Abesamis RA, Russ GR, Alcala AC (2006b) Gradients of abundance of fish across no take-take marine reserve boundaries: evidence from Philippine coral reefs. Aquat Conserv: Mar Freshw Ecosyst 16:349-371

Alarcón JA (2001) Inventory of artisanal fishery communities in the Western and Central Mediterranean. Reports and Studies COPEMED No. 6, Project FAO-COPEMED

Alcalá AC, Russ GR (1990) A direct test of the effects of protective management on abundance and yield of tropical marine resources. J Cons Int Explor Mer 46:40-47

Ashworth JS, Ormond RFG (2005) Effects of fishing pressure and trophic group on abundance and spillover across boundaries of a no-take zone. Biol Conserv 121:333-344

Bayle-Sempere JT (1999) Ictiofauna de la Reserva Marina de Tabarca (Alicante, Sudeste Ibérico): Evaluación de las medidas de protección. PhD thesis, University of Alicante

Becker RA, Chambers JM, Wilks AR (1988) The new S language. A programming environment for data analysis and graphics. Wadsworth \& Brooks/Cole Advanced Books \& Software, Pacific Grove, CA

Bell JD (1983) Effects of depth and marine reserve fishing restrictions on the structure of a rocky reef assemblage in the north-western Mediterranean Sea. J Appl Ecol 20: $357-369$
Beukers-Stewart BD, Vause BJ, Mosley MWJ, Rosetti HL, Brand AR (2005) Benefits of closed area protection for a population of scallops. Mar Ecol Prog Ser 298:189-204

> Chapman MR, Kramer DL (1999) Gradients in coral reef fish density and size across the Barbados Marine Reserve boundary: effects of reserve protection and habitat characteristics. Mar Ecol Prog Ser 181:81-96

Coll J, Linde M, García-Rubies A, Riera F, Grau AM (2004) Spear fishing in the Balearic Islands (west central Mediterranean): species affected and catch evolution during the period 1975-2001. Fish Res 70:97-111

Colloca F, Crespi V, Cesari S, Coppola SR (2004) Structure and evolution of the artisanal fishery in a southern Italian coastal area. Fish Res 69:359-369

> Davidson RJ, Villouta E, Cole RG, Barrier RGF (2002) Effects of marine reserve protection on spiny lobster (Jasus edwardsii) abundance and size at Tonga Island Marine Reserve, New Zealand. Aquat Conserv 12:213-227

> Dufour V, Jouvenel JY, Galzin R (1995) Study of a Mediterranean reef fish assemblage. Comparison of population distributions between depths in protected and unprotected areas over one decade. Aquat Living Resour 8:17-25

Dugan JE, Davis GE (1993) Applications of marine refugia to coastal fisheries management. Can J Fish Aquat Sci 50: 2029-2042

Galal N, Ormond RFG, Hassan O (2002) Effect of a network of no-take reserves in increasing catch per unit effort and stocks of exploited reef fish at Nabq, South Sinai, Egypt. Mar Freshw Res 53:199-205

García-Charton J, Pérez-Ruzafa A (1999) Ecological heterogeneity and the evaluation of the effects of marine reserves. Fish Res 42:1-20

- García-Charton JA, Pérez-Ruzafa A, Sánchez-Jerez P, BayleSempere JT, Reñones O, Moreno D (2004) Multi-scale heterogeneity, habitat structure, and effect of marine reserves on Western Mediterranean rocky reef fish assemblages. Mar Biol 144:161-182

García-Rubies A (1997) Estudi ecològic de les poblacions de peixos litorals sobre substrat rocós a la Mediterrània occidental: efectes de la fondària, el substrat, l'estacionalitat i la protecció. PhD thesis, University of Barcelona

García-Rubies A, Zabala M (1990) Effects of total fishing prohibition on the rocky fish assemblages of Medes Islands marine reserve (NW Mediterranean). Sci Mar 54: 317-328

Gerber LR, Bostford LW, Hastings A, Possinham HP, Gaines SD, Palumbi S, Andelman S (2003) Population models for marine reserve design. Ecol Appl (Suppl) 13:47-64

Goñi R, Latrouite D (2005) Biology, ecology and fisheries of Palinurus spp. species of European waters: Palinurus elephas (Fabricius, 1787) and Palinurus mauritanicus (Gruvel, 1911). Cah Biol Mar 46:127-142

> Goñi R, Quetglas A, Reñones O (2003) Differential catchability of male and female European spiny lobster Palinurus elephas (Fabricius, 1787) in traps and trammel nets. Fish Res 65:295-307

> Goñi R, Quetglas A, Reñones O (2006) Spillover of spiny lobsters Palinurus elephas from a marine reserve to an adjoining fishery. Mar Ecol Prog Ser 308:207-219

Halpern BS, Gaines SD, Warner RR (2004) Confounding effects of the export of production and the displacement of fishing effort from marine reserves. Ecol Appl 14:1248-1256

Harmelin JG (1987) Structure et variabilité de l'icthiyofaune d'une zone rocheuse protégée en Méditerranée (Parc Nationale de Port Cros, France). PSZN I: Mar Ecol 8: 263-284

Harmelin JG, Bachet F, Garcia F (1995) Mediterranean 
marine reserves: Fish indices as tests of protection efficiency. PSZN I: Mar Ecol 16:233-250

Harmelin-Vivien ML, Harmelin JG, Chauvet C, Duval R and others (1985) Evaluation visuelle de poblements et populations des poissons: méthodes et problèmes. Rev Ecol (Terre Vie) 40:467-539

Hastie T, Tibshirani R (1990) Generalized additive models. Chapman \& Hall, London

Hilborn R, Stokes K, Maguire JJ, Smith T and others (2004) When can marine reserves improve fisheries management? Ocean Coast Manage 47:197-205

Hilborn R, Micheli F, De Leo G (2006) Integrating marine protected areas with catch regulation. Can J Fish Aquat Sci 63:642-649

Johnson DR, Funicelli NA, Bohnsack JA (1999) Effectiveness of an existing estuarine no-take fish sanctuary within the Kennedy Space Center, Florida. N Am J Fish Manage 19: 436-453

Jouvenel JI, Bachet F, Harmelin JG, Bellan-Santini D (2004) Suivi biologique d'une reserve marine de la Côte Blueue (Golfe de Marseille, Méditerranée, France). Rev Ecol (Terre Vie) 59:243-251

Kaunda-Arara B, Rose GA (2004) Effects of marine reef National Parks on fishery CPUE in coastal Kenya. Biol Conserv 118:1-13

Kellner JB, Tetreault I, Gaines SD, Nisset RM (2007) Fishing the line near marine reserves in single and multispecies fisheries. Ecol Appl 17:1039-1054

Kelly S, Scott D, MacDiarmid AB (2002) The value of a spillover fishery for spiny lobsters around a marine reserve in New Zealand. Coast Manage 30:153:166

- Kramer DL, Chapman MR (1999) Implications for fish home range size and relocation for marine reserve function. Environ Biol Fishes 55:65-79

Maury O, Gascuel D (1999) SHADYS ('simulateur halieutique de dynamiques spatiales'), a GIS based numerical model of fisheries. Example application: The study of a marine protected area. Aquat Living Resour 12:77-88

McClanahan TR, Kaunda-Arara B (1996) Fishery recovery in a coral-reef marine park and its effect on the adjacent fishery. Conserv Biol 10:1187-1199

McClanahan TR, Mangi S (2000) Spillover of exploitable fishes from a marine park and its effects on the adjacent fishery. Ecol Appl 10:1792-1805

McCullagh P, Nelder JA (1989) Generalized linear models. Chapman \& Hall, London

Michelli F, Benedetti-Secci L, Gambaccini S, Bertocci J, Borsini C, Chato Osio G, Romano F (2005) Cascading human impacts, marine protected areas and the structure of Mediterranean fish assemblages. Ecol Appl 75: 81-102

Murawski SA, Wigley SE, Fogarty MJ, Rago PJ, Mountain DG (2005) Effort distribution and catch patterns adjacent to temperate MPAs. ICES J Mar Sci 62:1150-1167

> Ojeda-Martinez C, Bayle-Sempere J, Sánchez-Jerez P, Forcada A, Valle C (2007) Detecting conservation benefits in spatially protected fish populations with meta-analysis of long-term monitoring data. Mar Biol 151:1153-1161

Pelletier D, Ferraris J (2000) A multivariate approach for defining fishing tactics from commercial catch and effort data. Can J Fish Aquat Sci 57:51-65

Planes S (coordinator) (2005) Final report BIOMEX (Assessment of biomass export from marine protected areas and

Editorial responsibility: Matthias Seaman,

Oldendorf/Luhe, Germany its impacts on fisheries in the Western Mediterranean Sea) Project - UE - QLRT-2001-0891. BIOMEX Perpignan. Available at: http://biomex.univ-perp.fr/MEDIATEK/Final ReportBIOMEX.pdf

Rakitin A, Kramer DL (1996) Effect of a marine reserve on the distribution of coral reef fishes in Barbados. Mar Ecol Prog Ser 131:97-113

Ramos-Esplá AA, Valle-Pérez C, Bayle Sempere JT, SánchezLizaso JL (2004) Áreas Marinas Protegidas como herramientas de Gestión Pesquera en el Mediterráneo (Area COPEMED). Serie Informes y Estudios COPEMED no. 11. Available at : www.faocopemed.org/vldocs/0001014/index. $\mathrm{htm}$

Reñones O, Goñi R, Pozo M, Deudero S, Moranta J (1999) Effects of protection on the demographic structure and abundance of Epinephelus marginatus (Lowe, 1834). Evidence from the Cabrera Archipelago National Park (West Central Mediterranean). Mar Life 9:45-53

Roberts CM, Polunin NVC (1991) Are marine reserves effective in management of reef fisheries? Rev Fish Biol Fish 1:65-91

Roberts CM, Bohnsack JS, Gell FR, Hawkins JP, Goodridge R (2001) Effects of marine reserves on adjacent fisheries. Science 294:1920-1923

Rodwell LD, Roberts CM (2004) Fishing and the impact of marine reserves in a variable environment. Can J Fish Aquat Sci 61:2053-2068

Russ GR (2002) Yet another review of marine reserves as reef fishery management tools. In: Sale P (ed) Coral reef fishes. Academic Press, San Diego, CA, p 421-443

Russ GR, Alcala AC (1996) Do marine reserves export adult fish biomass? Evidence from Apo Island, central Philippines. Mar Ecol Prog Ser 132:1-9

Russ GR, Alcalá AC, Maypa AP (2003) Spillover from marine reserves: the case of Naso vlamingii at Apo Island, the Philippines. Mar Ecol Prog Ser 264:15-20

Russ GR, Alcalá AC, Maypa AP, Calumpong HP, White AT (2004) Marine reserve benefits local fisheries. Ecol Appl 14:597-606

Sánchez Lizaso JL, Goñi R, Reñones O, García-Charton JA and others (2000) Density dependence in marine protected populations: a review. Environ Conserv 27:144-158

Tewfik A, Bene C (2003) Effects of natural barriers on the spillover of a marine mollusc: implications for fishery reserves. Aquat Conserv: Mar Freshwat Ecosyst 13:473-488

Tupper MH (2007) Spillover of commercially valuable reef fishes from marine protected areas in Guam, Micronesia. Fish Bull (Wash DC) 105:527-537

Walters C (2000) Impacts of dispersal, ecological interactions and fishing effort dynamics on efficacy of marine protected areas: How large should protected areas be? Bull Mar Sci 6:745-757

Wilcox C, Pomeroy C (2003) Do commercial fishers aggregate around marine reserves? Evidence for Big Creek marine ecological reserve, Central California. N Am J Fish Manage 23:241-250

Willis TJ, Millar RB, Babcock RC (2003) Protection of exploited fish in temperate regions: high density and biomass of snapper Pagrus auratus (Sparidae) in northern New Zealand marine reserves. J Appl Ecol 40:214-227

Yamasaki A, Kuwahara A (1989) Preserved area to effect recovery of overfished Zuwai crab stocks off Kyoto Prefecture. Proc Int Symp of King and Tanner Crabs, November 1989, Anchorage, AL, p 575-585

Submitted: July 5, 2007; Accepted: April 21, 2008

Proofs received from author(s): August 19, 2008 